\title{
The terms of trade for commodities in the twentieth century
}

\section{José Antonio Ocampo}

Executive Secretary,

ECLAC

jaocampo@eclac.cl

María Ángela Parra

Adviser to the Executive

Secretary of ECLAC

aparra@eclac.cl 


\section{Introduction}

This paper examines the evolution of the international terms of trade for commodities in the light of recent empirical evidence. The analysis is divided into nine sections. Section II provides a brief summary of the theoretical foundations for what is known as the PrebischSinger hypothesis. Section III presents the evidence, in the most straightforward manner possible, of the evolution of relative prices (or barter terms of trade) for commodities as compared to manufactures. Section IV provides an analysis of the autoregressive dynamics of the series, while section $V$ assesses the possible existence of structural breaks. In section VI, the dynamics of the series are examined by drawing upon the analysis set forth in the preceding two sections. Section VII looks at the evolution of the stationary series and identifies two points in time when major changes occurred (1921 and 1979). Section VIII provides a brief discussion of the persistence of shocks in the short and medium terms. The study's findings are interpreted in section IX.

The empirical analysis employs price series for 24 commodities, seven indices constructed by Grilli and Yang (1988) and, as an alternative index, the industrial commodities price index calculated by The Economist. In order to cover the entire twentieth century, the indices developed by Grilli and Yang have been updated to 2000 using these authors' original methodology. A detailed description of the products and indices is provided in section III.

\section{II}

\section{The Prebisch-Singer hypothesis}

The thesis concerning the declining trend of the terms of trade ${ }^{1}$ for developing countries was formulated concurrently by Sir Hans Singer and Raúl Prebisch ${ }^{2}$ in the early 1950s. Their work in this area was, in large part, undertaken in an effort to account for the empirical research findings of the United Nations Department of Economic and Social Affairs, which corroborated the existence of such a trend. ${ }^{3}$ The original formulation of this thesis combined two different yet clearly complementary hypotheses whose subsequent theoretical development in the economic literature was

$\square$ This essay was prepared as a background paper to the Globalization and Development report (ECLAC, 2002). The authors wish to thank Oscar Altimir, André Hoffman, Raimundo Soto and Daniel Titelman for their comments and Claudia de Camino and Jaime Contador for their data processing work. They are also grateful to Paul Cashin and John Cuddington for their willingness to share their databases on the subjects covered.

${ }^{1}$ See Scandizzo and Diakosawas (1987) for the different meanings attached to the term.

${ }^{2}$ See Singer (1950) and Prebisch (1950).

${ }^{3}$ The relevance and reliability of the data used have been debated at length. See, in particular, Scandizzo and Diakosawas (1987). to follow parallel courses. One of these hypotheses regarded the negative effect of the income-inelasticity of the demand for commodities on developing countries' terms of trade, while the other dealt with the asymmetries in the functioning of labour markets in the world economy's "centre" and "periphery". The fundamental conceptual difference between these two hypotheses lies in the fact that, whereas in the first case the pressure towards a deterioration in real commodity prices is generated through goods markets (i.e., on the barter terms of trade), in the second this pressure is generated through factor markets (and hence on the factorial terms of trade) and thus affects the barter terms of trade only indirectly, through the effects on production costs. Another difference, which is a consequence of the foregoing, is that whereas the first hypothesis applies solely to commodities (or, more generally, to goods whose demand exhibits a low income-elasticity), the second applies to all goods and services produced in developing countries, regardless of their type or the nature of final demand.

The first hypothesis was based on the well-known observation that economic growth tends to trigger

THE TERMS OF TRADE FOR COMMODITIES IN THE TWENTIETH CENTURY • JOSÉ ANTONIO OCAMPO AND MARÍA ÁNGELA PARRA 
changes in the production structure over time and, in particular, to generate a tendency towards a reduction in the relative size of the primary sector. As is widely recognized, this structural break is associated not only with the characteristics of final demand (especially the low income-elasticity of the demand for foodstuffs) but also with the fact that, in many cases, technological change in the production of manufactures entails reductions in raw material costs or the production of synthetic materials. These variations in the production structure have major implications at the world level if the international division of labour is such that developing countries specialize in the production of raw materials while industrialized nations specialize in manufactures. Under these circumstances, it is to be expected that either the former will grow more slowly or the surplus of commodities they produce will tend to push down the relative international prices of those commodities. $^{4}$

The second hypothesis was formulated by both authors -although perhaps more clearly by Singer- in terms of an unequal distribution of the benefits of technological progress. According to this hypothesis, in the case of manufactures these benefits accrue to producers in the form of higher income, but in the case of commodities they are reflected in lower prices. This asymmetry results from the operation of both goods markets (greater market power for setting the prices of manufactures) and labour markets (greater organization of industrial workers). At the international level, however, it also reflects the problems of the international division of labour. In this instance, the more precise formulation was Prebisch's. According to his view, the weaker long-term demand for raw materials means that the relative surplus of labour displaced from primary activities tends to concentrate in developing countries which, in turn, have more difficulty putting that surplus labour to work in new production sectors. The problems they face include political restrictions on migration to industrialized nations and obstacles to late industrialization in developing countries, associated, in Prebisch's hypothesis, with the large disparities between

\footnotetext{
4 The pressure towards unequal rates of growth will be greater if the externalities generated by production (the generation of demand multipliers and the externalities associated with technical progress, in particular) are greater in the case of industrial production. This was also one of the core elements of the two authors' thesis, but will not be discussed further here. See Hadass and Williamson (2001) for an interesting recent empirical assessment of this question covering the period 1870-1940.
}

the countries of the "centre" and the "periphery" in terms of technological capabilities and the availability of capital. This situation generates a surplus of labour which leads to a relative decline in the wages of developing-country workers and, hence, in those countries' terms of trade. ${ }^{5}$

The history of the controversy surrounding the issue of developing countries' terms of trade can largely be written by tracing the development of these two hypotheses. ${ }^{6}$ The neoclassical and Keynesian literature of the 1950s and 1960s focused on the first of them. According to Johnson (1954), the lower incomeelasticity of the demand for raw materials ought to be reflected in slower economic growth in the countries specializing in those products or in a tendency for raw material prices to decline. This effect depends entirely on income-elasticity, but the lower the price-elasticity of the demand for raw materials is, the larger the decrease will be. It should be emphasized, however, that this type of model is incapable of generating asymmetries in the transmission of technical progress, and thus cannot be used to validate the second PrebischSinger hypothesis.

In a neoclassical (Heckscher-Ohlin) trade model, any factor that increases the supply of a given good will result in a decrease in its relative price. Thus, in countries or regions that are large enough to influence international prices, technological change in export industries will be reflected in a deterioration of the terms of trade. Conversely, technological change in importsubstitution industries will have just the opposite effect, since it will cause factors of production to be transferred to those sectors, thereby reducing the supply of exports and, consequently, improving the terms of trade.

Unlike this line of reasoning, the analysis of "unequal exchange" since the late 1960s has focused on asymmetries in the operation of labour markets. The most comprehensive treatments of this subject are based on the models developed by Findlay (1980 and 1981) and Taylor (1983, chapter 10) in the early 1980s. ${ }^{7}$ In both cases, the economy being modelled is one in which

\footnotetext{
${ }^{5}$ Prebisch (1950) believed that this asymmetry was particularly evident during downswings in the business cycle. In his view, workers in countries of the centre were not only able to secure wage increases during booms, but were also able to defend their wages during recessionary phases in the world business cycle. In contrast, the surplus of raw materials, and hence the marked cyclical deterioration in their prices, meant that workers in the periphery were unable to prevent their incomes falling during crises.

${ }^{6}$ See Ocampo (1986 and 1993).

${ }^{7}$ See Ocampo (1986) for a comparison of these and other models.
} 
the "North" sets the pace of world economic growth and the "South" adapts to that pace. The essential element of this model is, however, its recognition of the asymmetries in the economic structures of the two. Thus, the North has a neoclassical economic structure in Findlay's model and a Keynesian (or, more accurately, Kaleckian) structure in Taylor's, while in both formulations the South functions as a Lewis-type surplus-labour economy. These asymmetries give rise to a pattern that fits perfectly with the second PrebischSinger hypothesis, i.e., in the long run the North appropriates the full benefits of its own process of technical change, while the South's productivity gains lead to a commensurate deterioration in its barter terms of trade (in other words, its technical changes are "exported"). This is a reflection of the asymmetrical effects that technological change has on real wages. While wage increases in the North are proportional to increases in productivity, in the South real wages are not affected by technological change. The corresponding effect is transmitted through production costs and is therefore unrelated to the type of good being produced or the demand for it. ${ }^{8}$

Over the last two decades, the empirical literature on this issue has been greatly enriched, ${ }^{9}$ thanks to the existence of more reliable data and new, more rigorous statistical methodologies for analysing time series. In the following sections, these methodologies are used to analyse the validity of a thesis that has already been around for half a century. It should be added that, given available data, the empirical assessment refers chiefly to the barter terms of trade. Nevertheless, the abundant recent literature on the international "convergence" or "divergence" of per capita incomes and wages can, in a sense, be regarded as a contribution to the clarification of the second above-mentioned hypothesis regarding the trend in the factorial terms of trade. ${ }^{10}$

\section{III \\ Preliminary analysis of the trend in real commodity prices}

This analysis is based primarily on 24 commodity price series $^{11}$ and seven indices which were originally developed by Grilli and Yang (1988) for the period 1900-1986, but which have been updated to the year 2000 in order to cover the entire century. ${ }^{12}$ The deflator

\footnotetext{
${ }^{8}$ Consequently, contrary to the argument made by Hadass and Williamson (2001), this effect should be modelled under the assumption of equivalent (unitary) income elasticities for goods produced by the two regions.

${ }^{9}$ See, among others, Cuddington and Urzúa (1989), Powell (1991), Ardeni and Wright (1992), Cuddington (1992), Cuddington and Wei (1998), Bleany and Greenaway (1993), León and Soto (1995a and 1995b), Cashin and McDermott (2002) and Cuddington, Ludema and Jayasuriya (2002).

${ }^{10}$ See ECLAC (2002, chapter 3 ) for a summary of the conclusions reached in the course of this debate and some additional calculations.

${ }^{11}$ The commodities are: six metals (aluminium, copper, lead, silver, tin and zinc), seven non-food raw materials (cotton, hides, jute, palm oil, rubber, timber and wool), seven foods (bananas, beef, lamb, maize, rice, sugar and wheat), three beverages (cocoa, coffee and tea) and tobacco. John Cuddington of Georgetown University was kind enough to make these series available to the authors.

12 The indices covering the period from 1986 to 2000 and the methodology used to update them are presented in appendix A.
}

used to calculate real prices is the manufacturing unit value (MUV) index developed by the United Nations. ${ }^{13}$ As an alternative, the industrial commodity price index of The Economist for 1880-1999 is also used. ${ }^{14}$ The deflator used in this case was the Great Britain Index of Export Prices ${ }^{15}$ for 1880-1900 and the MUV thereafter. Section A of figure 1 shows the total Grilli and Yang price indices. The nomenclature used in the rest of the paper is explained in box 1 .

\footnotetext{
${ }^{13}$ This index reflects the unit value of industrialized countries' exports of manufactured products. It was originally taken from Grilli and Yang (1988) and later updated using the series compiled by the Statistics Division of the United Nations Department of Economic and Social Affairs.

${ }^{14}$ This series includes prices for six metals (aluminium, copper, lead, nickel, tin and zinc) and nine non-food commodities (coconut oil, cotton, hides, palm oil, rubber, soya oil, soybeans, timber and wool). The authors were able to obtain this series thanks to the generous assistance of Paul Cashin of the International Monetary Fund (IMF) Research Department.

15 This index (developed by A.G. Silverman) was chosen due to the absence of alternative data and the importance of this country in world trade in the late nineteenth century.
} 
FIGURE 1

\section{Non-petroleum commodity price indices}

$(1900=100)$

A. Total indices

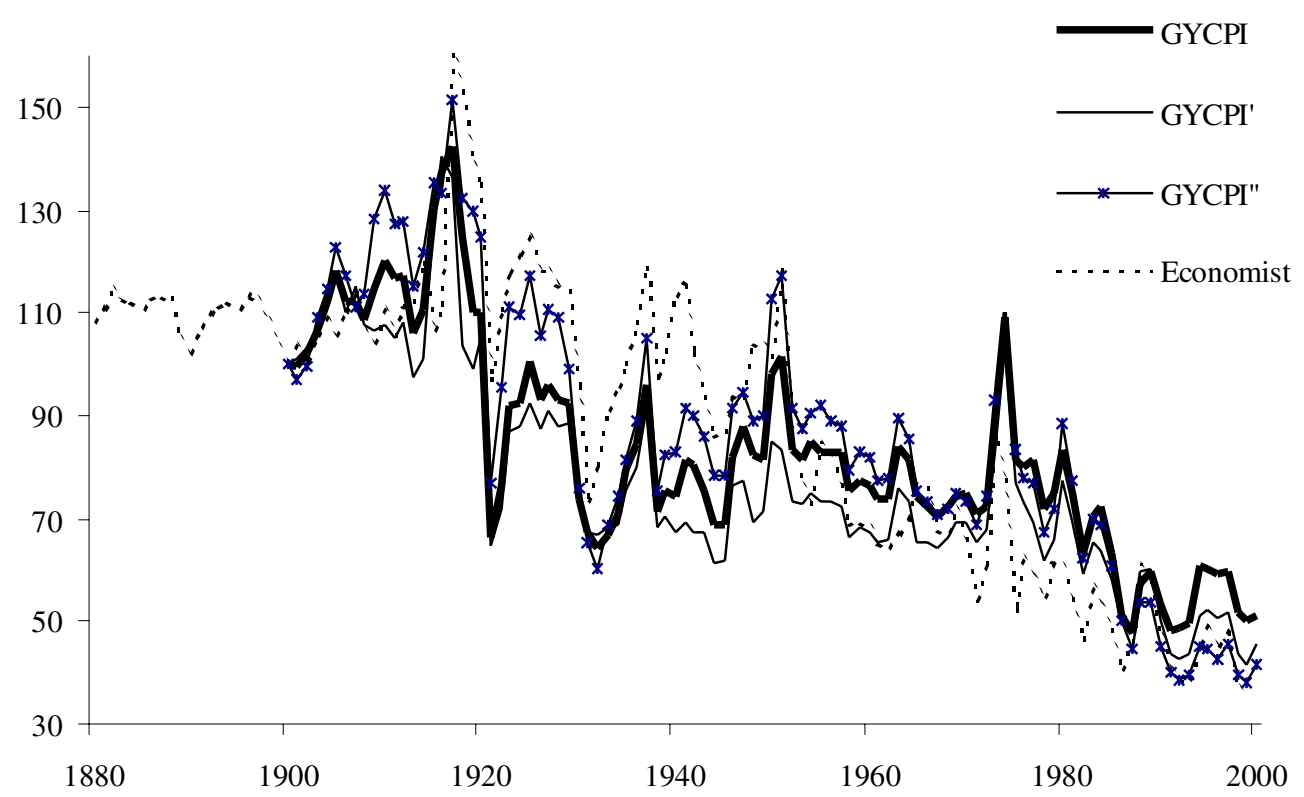

B. GYCPI

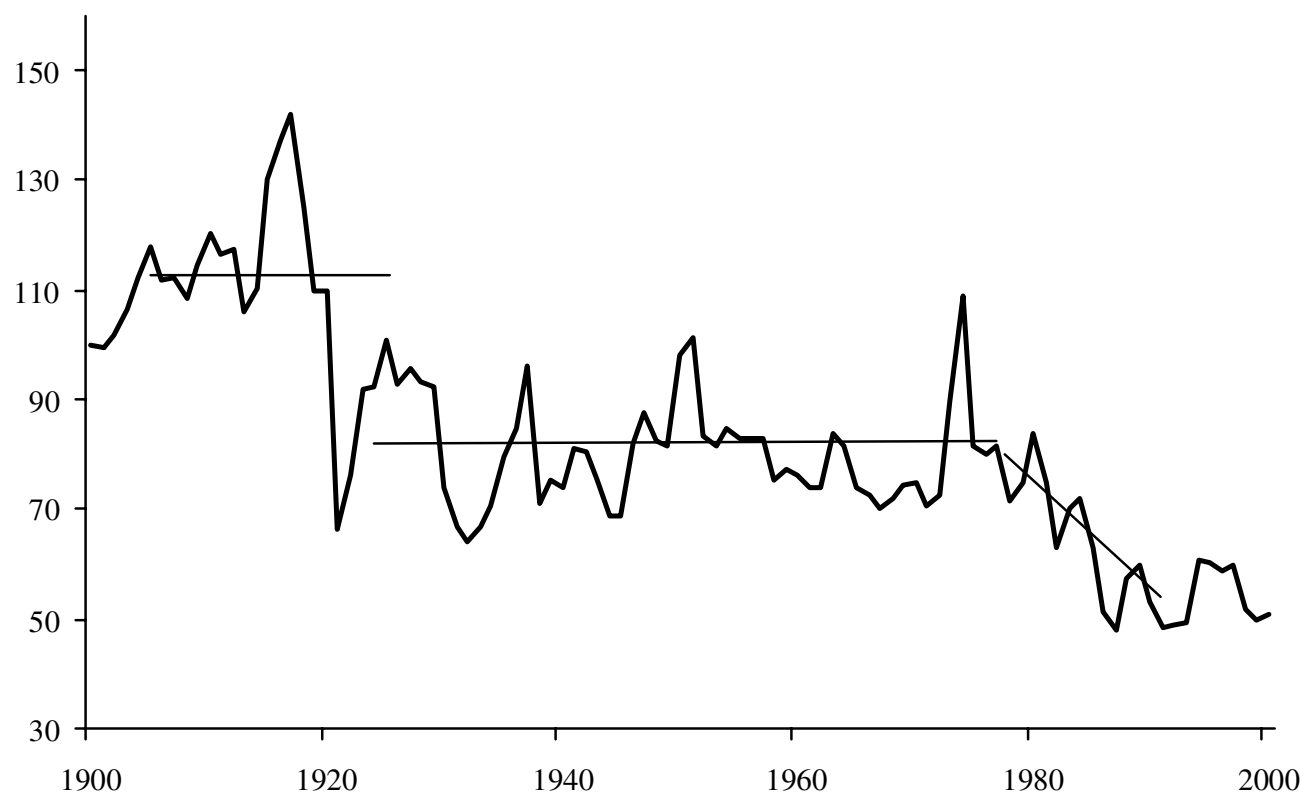

Source: Grilli and Yang (1988) and authors' calculations.

THE TERMS OF TRADE FOR COMMODITIES IN THE TWENTIETH CENTURY • JOSÉ ANTONIO OCAMPO AND MARÍA ÁNGELA PARRA 


\begin{abstract}
Box 1
NOMENCLATURE

Following the nomenclature employed by Grilli and Yang, seven dollar-denominated price indices (four aggregate indices and three sub-indices) for internationally traded commodities will be considered:

GYCPI: Total index, weighted by each product's share of total exports in 1977-1979. Three sub-indices are derived from this: foods, non-foods and metals.

GYCPI': Total index, weighted by the developing countries' share of commodity exports in 1981. (The original index used weightings for 1977-1979; since these were unavailable, 1981 weightings were used instead).

GYCPI": Total index, weighted by the share of world exports represented by commodities during the current year. GYCPI": The same as GYCPI" except that it includes the petroleum price.
\end{abstract}

Despite the differences between the series caused by the varying weightings of the commodities' export shares and the cyclical variability of each series, a marked long-term decline in real prices is clearly seen. Taken as a whole, the cumulative decrease is very large, since by 2000 raw materials had lost between $50 \%$ and $60 \%$ of their pre-1920 value relative to manufactures. This finding has been corroborated by various authors. ${ }^{16}$ Cashin and McDermott (2002), for example, found a downward trend without structural breaks of $1.3 \%$ per year over a period of 140 years, ${ }^{17}$ which, oddly enough, they interpret as very small compared to the variability of the series, even though it translates into a cumulative decline of $75 \%$ over the period they analysed.

This downturn is a hallmark of the twentieth century, not the nineteenth. In fact, in keeping with the recent observations of Hadass and Williamson (2001), the series actually point to an improvement in real raw material prices in the late nineteenth and early twentieth centuries. ${ }^{18}$ These authors have also noted that the sharp reduction in shipping costs that occurred during those years benefited all countries. This is reflected in the improvement that can be seen in the terms of trade for the period when prices are measured in a given location (i.e., fob export prices versus cif import prices).

\footnotetext{
${ }^{16}$ See, for example, a summary of the studies conducted up to the 1980s in Ocampo (1993).

17 Cashin and McDermott use The Economist's industrial commodity price series for the period 1862-1999 and then convert it to a relative price series using United States GDP as a deflator.

${ }^{18}$ A number of partial (country) studies also provide evidence that raw material prices rose in real terms throughout the nineteenth century.
}

It is important to note that this decrease has not been continuous. Instead, it has occurred in stepwise shifts that appear to have permanently altered price levels. Section B of figure 1 reproduces the GYCPI series, highlighting what appear to be shifts of this kind. It is noteworthy that the largest price drops followed, with a lag, the two major slowdowns in the industrialized economies' long-term growth rates, occurring during the First World War and in 1973 (see Maddison, 1995).

These observations suggest that, rather than discussing whether or not there was a long-term downtrend in the barter terms of trade for raw materials during the twentieth century, it would be more to the point to talk about the particular dynamics exhibited by this decline and the differences in price movements for individual products. The Prebisch-Singer hypothesis has traditionally -and perhaps erroneously- ${ }^{19}$ been associated with a secular or continuous trend. This study considers the hypothesis that this deterioration occurred in steps. The exploration of this possibility is based on a detailed analysis of the behaviour of aggregate price indices and individual product prices.

A preliminary view of the situation is outlined in table 1, which shows the average annual growth rates of the series for the two stages during which the sharpest decreases were seen and for the period as a whole and gives calculations of the loss in relative value that occurred between the first and last five years of the twentieth century. The data show that product behaviour was quite heterogeneous. Regardless of the weighting used, however, all the indices show average declines of

\footnotetext{
19 Cuddington, Ludema and Jayasuriya (2002) contend that the Prebisch-Singer hypothesis did not claim that the long-term trend was necessarily constant over time, but only that it was negative.
} 
TABLE 1

Commodity prices and indices deflated by the United Nations manufactures unit value (MUv) index

(Average annual growth rates)

\begin{tabular}{|c|c|c|c|c|c|}
\hline & \multirow[t]{2}{*}{$1920-1930$} & \multirow[t]{2}{*}{ 1980-1990 } & \multirow[t]{2}{*}{$1900-2000$} & \multicolumn{2}{|c|}{ 1900/1904-1996/2000 } \\
\hline & & & & Annual & Cumulative \\
\hline \multicolumn{6}{|l|}{ Commodity } \\
\hline Aluminium & 1.8 & 2.8 & -1.1 & -1.3 & -71.7 \\
\hline Bananas & 5.8 & 0.1 & 0.0 & -0.1 & -7.5 \\
\hline Beef & -0.2 & -6.6 & 1.0 & 0.9 & 134.6 \\
\hline Cocoa & -0.7 & -9.5 & -1.3 & -1.0 & -61.8 \\
\hline Coffee & 0.4 & -8.3 & -0.1 & 0.4 & 45.3 \\
\hline Copper & 1.4 & -1.1 & -0.7 & -0.6 & -46.0 \\
\hline Cotton & -3.0 & -6.1 & -1.0 & -1.1 & -66.0 \\
\hline Jute & -0.9 & 0.6 & -0.4 & -0.7 & -30.4 \\
\hline Lamb & -0.1 & -3.9 & 1.6 & 1.7 & 399.3 \\
\hline Lead & 0.7 & -4.2 & -0.8 & -0.3 & -48.0 \\
\hline Leather & -4.7 & 1.3 & -0.8 & -1.1 & -63.6 \\
\hline Maize & -1.2 & -5.3 & -0.8 & 1.2 & -61.9 \\
\hline Palm oil & -2.8 & -2.8 & -0.3 & 0.0 & -1.3 \\
\hline Rice & 3.7 & -6.9 & -1.3 & -1.2 & -66.9 \\
\hline Rubber & -9.5 & -7.9 & -2.8 & -2.8 & -93.4 \\
\hline Silver & -5.3 & -16.2 & -0.3 & -1.0 & -23.8 \\
\hline Sugar & -16.8 & -10.5 & -1.3 & -1.1 & -65.4 \\
\hline Tea & 7.6 & -4.0 & -0.7 & 0.7 & -56.2 \\
\hline Timber & -2.2 & -1.5 & 1.1 & -1.5 & 208.1 \\
\hline Tin & 0.1 & -10.2 & 0.1 & 0.2 & 15.4 \\
\hline Tobacco & -2.7 & -0.4 & 0.8 & -0.7 & 100.4 \\
\hline Wheat & -4.5 & -3.1 & -0.6 & -0.9 & -46.4 \\
\hline Wool & -3.1 & -5.5 & -1.2 & -0.4 & -76.6 \\
\hline Zinc & -0.9 & 4.7 & 0.3 & 0.1 & 5.9 \\
\hline \multicolumn{6}{|l|}{ Index } \\
\hline GYCPI & -3.9 & -4.4 & -0.7 & -0.7 & -47.8 \\
\hline GYCPI' & -3.7 & -4.2 & -0.8 & -0.8 & -55.4 \\
\hline GYCPI", & -4.9 & -6.5 & -0.9 & -1.0 & -60.2 \\
\hline GYCPI", & -5.1 & -6.1 & -0.4 & -0.7 & -49.3 \\
\hline Foods & -5.2 & -7.8 & -0.8 & -0.7 & -49.8 \\
\hline Non-foods & 1.2 & 5.1 & 0.0 & -0.2 & -14.6 \\
\hline Metals & 5.5 & 0.9 & -0.1 & -0.1 & -7.1 \\
\hline The Economist & -3.4 & -2.5 & -1.0 & -1.0 & -60.1 \\
\hline
\end{tabular}

Source: Authors' calculations based on Grilli and Yang (1988) and on data from the United Nations and The Economist.

$0.8 \%$ per year due to the decrease in the relative value of food products, which was particularly steep during the 1920 s and the 1980s. While non-food products lost some $15 \%$ of their purchasing power in the course of the century, food products lost about half. The only commodities whose relative value rose substantially over the century as a whole were beef, lamb, timber and tobacco.

The following analysis deals with the dynamic structure of each series. While it is clear that during the twentieth century most commodities' purchasing power dropped significantly, neither the size of this cumulative decrease nor the average annual growth rates provide a basis from which to infer the series' long-term growth behaviour. ${ }^{20}$ In order to understand this behaviour, it is essential to know how the series respond to shocks and, in particular, whether or not they have a stochastic component. It is also important to evaluate the possibility that the series exhibit structural breaks before using all the information that has been compiled to model the behaviour of each one as completely as possible.

\footnotetext{
${ }^{20}$ As Cuddington, Ludema and Jayasuriya (2002) have noted, modern time series econometrics has taught us that it is potentially misleading to assess the presence of long-term trends through visual examination of series or estimation of simple log-linear time trend models.
} 


\section{IV}

\section{Autoregressive dynamics of the series}

A distinction should be drawn between two types of autoregressive processes that may give rise to statistical trends displaying different dynamics: a deterministic trend (DT), if the series are stationary in variance, and a stochastic trend (ST), if they exhibit properties of nonstationarity in variance. ${ }^{21}$

A deterministic trend (DT) model exhibits the following dynamics:

$$
\log P_{t}=\beta T_{t}+\operatorname{ARMA}(p, q) e_{t}
$$

where $T_{t}$ is a trend variable, $e_{t}$ is an independent and identically distributed random shock and the parameter $\beta$ is the trend (exponential growth rate), which can be estimated using traditional econometric procedures (ordinary least squares). The use of the term $A R M A^{22}$ for the residual rules out the possibility of a misspecification caused by higher order autocorrelations of the series. In this model, the series $P_{t}$ is not stationary (unless $\beta=0$ ), but the fluctuations of $P_{t}$ around its DT are stationary (there is no evidence of a unit root). The only information required in this model in order to forecast the long-term price trend is the average growth rate of the variable $\beta$, since shocks, being wholly transitory, will not affect long-term projections.

In turn, a stochastic or stationary trend (ST) model in differences has the following dynamics:

$$
\Delta \log P_{t}=\gamma+\operatorname{ARMA}\left(p^{\prime}, q^{\prime}\right) \mu_{t}
$$

where $\Delta$ is the first differences operator and $\gamma$ is the average growth rate of the variable. The presence of $\mu_{\mathrm{t},}^{23}$ an independent and identically distributed random variable, will induce stochastic behaviour in price levels. This model would be appropriate if the series were

\footnotetext{
${ }^{21}$ See, among others, León and Soto (1995a) and Cuddington, Ludema and Jayasuriya (2002).

${ }^{22}$ Combination of an autoregressive process indicating that today's value depends on the values of the variable in the past (AR) and a moving average process where the value of the variable depends on errors in the past (MA).

${ }^{23}$ It is important to emphasize that, whereas $e_{t}$ is a random shock that does not affect the trend of the series, $\mu_{t}$ is a random variable whose presence induces stochastic behaviour in the trend.
}

found to have a unit root. Consequently, in addition to a possible deterministic trend $(\gamma)$, in this case shocks can have permanent effects on commodity price levels. If $\gamma$ is statistically significant, then we have a unit root process with drift.

Applying this logic to the GYCPI, Cuddington, Ludema and Jayasuriya (2002) show that the possibility of finding a statistically significant trend hinges critically upon the conclusions derived from a unit root test. More specifically, these authors show that, if the index is found to be following a DT process, then the trend can be regarded as significant (of the order of $0.3 \%$ per year). If, on the other hand, it is found that it follows an ST process, then the high variance of the series in differences means that the null hypothesis of a zero growth rate cannot be rejected.

As a first step towards determining which model was the most appropriate for each of the series being analysed, the unit root hypothesis was subjected to both augmented Dickey-Fuller (ADF) and non-parametric Phillips-Perron tests. The detailed results are presented in appendix B. As can be seen, the ADF tests do not rule out the null hypothesis of non-stationarity (existence of unit root) for seven of the eight indices and 18 of the 24 commodities. When the Phillips-Perron tests are run, the same thing occurs in the case of two indices and 14 commodities. ${ }^{24}$

These results are far from conclusive and, given their importance for the prospects of obtaining a statistically significant trend, further work is called for in this area. In some studies, furthermore, it has been found that these two tests wrongly tend not to rule out

\footnotetext{
${ }^{24}$ Using the same data, Cuddington (1992) shows that 12 of the 24 products can be modelled as non-stationary processes for the period 1900-1983. The results tally with those presented in appendix B, but with some important exceptions. For the period 1900-2000, coffee, lead and tin prices exhibit characteristics of non-stationarity that did not arise in Cuddington's results, which were also used by León and Soto (1995a). Going by the results of the Dickey-Fuller test, meanwhile, these authors find jute and rubber to be nonstationary, but in this study they are regarded as stationary, as the Phillips-Perron test shows this to be so at a $90 \%$ confidence level. If, however, we take a $95 \%$ confidence level as a minimum significance requirement, as these authors did, then jute, rice and rubber prices would be non-stationary, as would the variable weightings index.
} 
the null hypothesis of a unit root, especially if the series has structural breaks. ${ }^{25}$ What is more, if finite samples are being used and the shocks dissipate slowly, there may be very few independent observations of the process and, in that context, the estimation of DT models may generate more reliable estimates of the parameters (León and Soto, 1995b). In the case being discussed here, a number of authors have found proof of the existence of structural breaks or instability in the parameters. ${ }^{26}$ In this instance, furthermore, the sample is finite and the speed at which the shocks dissipate is unknown.

For these reasons, an alternative method must be used in order to ascertain the persistence of shocks in the structure of the series. If persistence is high, the series may be regarded as non-stationary, since the shocks will become a quasi-permanent component of it. On the other hand, if shocks dissipate rapidly, the behaviour of the series will be stationary over time. This is effectively a non-parametric test for the existence of a unit root.

In order to conduct such a test using the same approach as León and Soto (1995a and 1995b), recursive estimation procedures were employed to determine the ratio between the variance of innovations and the variance of the series. This estimator (known as Vk) makes it possible to see, from period to period (recursively), whether a shock changes the series' variability temporarily or permanently. ${ }^{27}$ Its interpretation is explained in box 2 . The Vk estimator also makes it possible to describe the response of the barter terms of trade in accordance with the dissipation pattern characterizing them (see section VIII).

The results of this estimation are presented in figure $2 .^{28}$ The solid lines depict the trend of the Vk estimator from period to period and the dotted lines its $95 \%$ confidence interval. If $\mathrm{Vk}$ (or its confidence interval) trends towards 1 over the period, then the series is exhibiting a high level of persistence in the face of shocks, so the series being analysed is not stationary. ${ }^{29}$

\footnotetext{
25 León and Soto (1995a and 1995b) and Perron (1989).

26 See, in particular, Cuddington, Ludema and Jayasuriya (2002). The issue will be examined in greater depth in the following section.

27 See Cochrane (1988). A detailed explanation of this procedure is given in León and Soto (1995b).

28 To calculate this estimator we used the program written by Paco Goerlich for RATs. This software is based on cochrane2.src (Cochrane, 1988) and is available at www.estima.com.

29 The way in which the estimator was constructed (León and Soto, $1995 \mathrm{a}$ and 1995b) causes the initial values to be close to 1 , but what is important is its convergence towards or divergence from $\mathrm{Vk}=1$.
}

Box 2

\section{INTERPRETATION OF THE VK ESTIMATOR}

The variance ratio can be interpreted as a measurement of the significance of the permanent component as follows: if a series $Y t$ follows a DT process, then no innovation has a permanent effect (i.e., the permanent component is nil). Thus, in the long run, the variance of innovations and the $\mathrm{Vk}$ estimator will trend towards zero. If $Y t$ is a random walk, then innovation is wholly captured by the permanent component, so the variance of innovations will tend to equal the variance of the series and the variance ratio will be 1 . In an intermediate process such as the ST process, lastly, Vk will be between 0 and 1 .

As figure 2 shows, this approach confirms the nonstationarity hypothesis for the prices of six commodities: aluminium, bananas, cocoa, cotton, silver and tobacco. The estimator does not provide conclusive evidence in the cases of tea and wool, and these series are therefore considered to be non-stationary, as indicated by the earlier tests. In relation to the prices of the remaining products and the indices, ${ }^{30}$ conversely, the null hypothesis of $\mathrm{Vk}$ trending towards 1 can be rejected and it can thus be concluded that they do not exhibit non-stationarity. ${ }^{31}$

Although the analysis conducted up to this point would lead us to believe that the sT model should be estimated for eight products (aluminium, bananas, cocoa, cotton, silver, tea, tobacco and wool) and that the DT model should be used for the remaining products and all the indices, our basic hypothesis is that the deterioration in price indices occurred in a stepwise fashion, which would point to the presence of structural breaks in the series. ${ }^{32}$ This issue will be dealt with now.

\footnotetext{
30 The standard tests thus yielded biased results for beef, coffee, copper, lead, tin and the foods and metals indices.

${ }^{31}$ If these results are compared with the findings of León and Soto (1995a), a number of differences arise. Whereas they found the prices of cocoa, silver and tea to be stationary during 1900-1992, our estimates for 1900-2000 indicate that they are non-stationary. 32 Cuddington, Ludema and Jayasuriya (2002) contend that, regardless of whether a DT or ST specification is chosen, there is evidence that one or more breaks or instabilities in the parameters may be the problem.
} 
FIGURE 2

Recursive estimates of persistence (Vk)

(Vertical axis: Vk; horizontal axis: time)
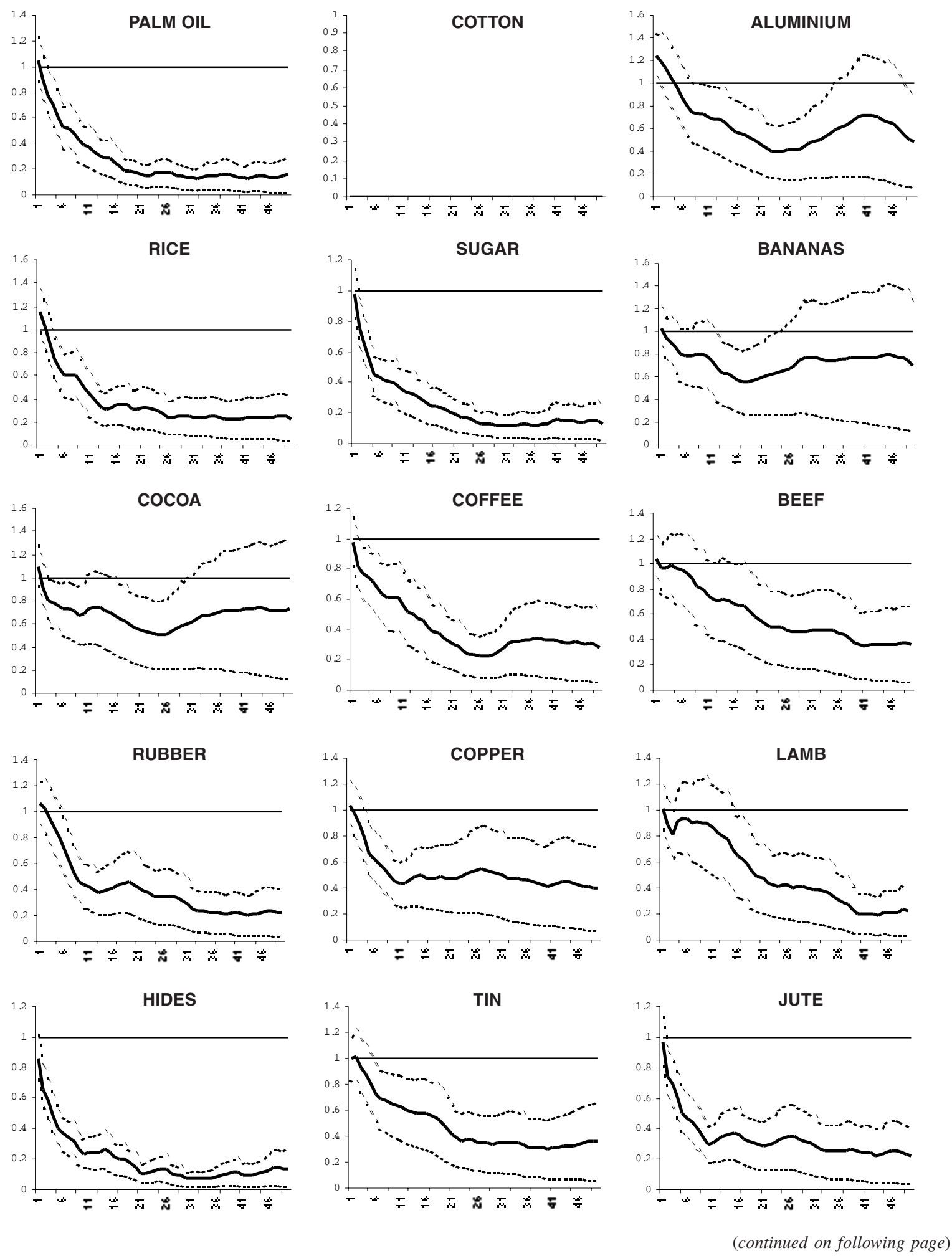
Figure 2 (continued)
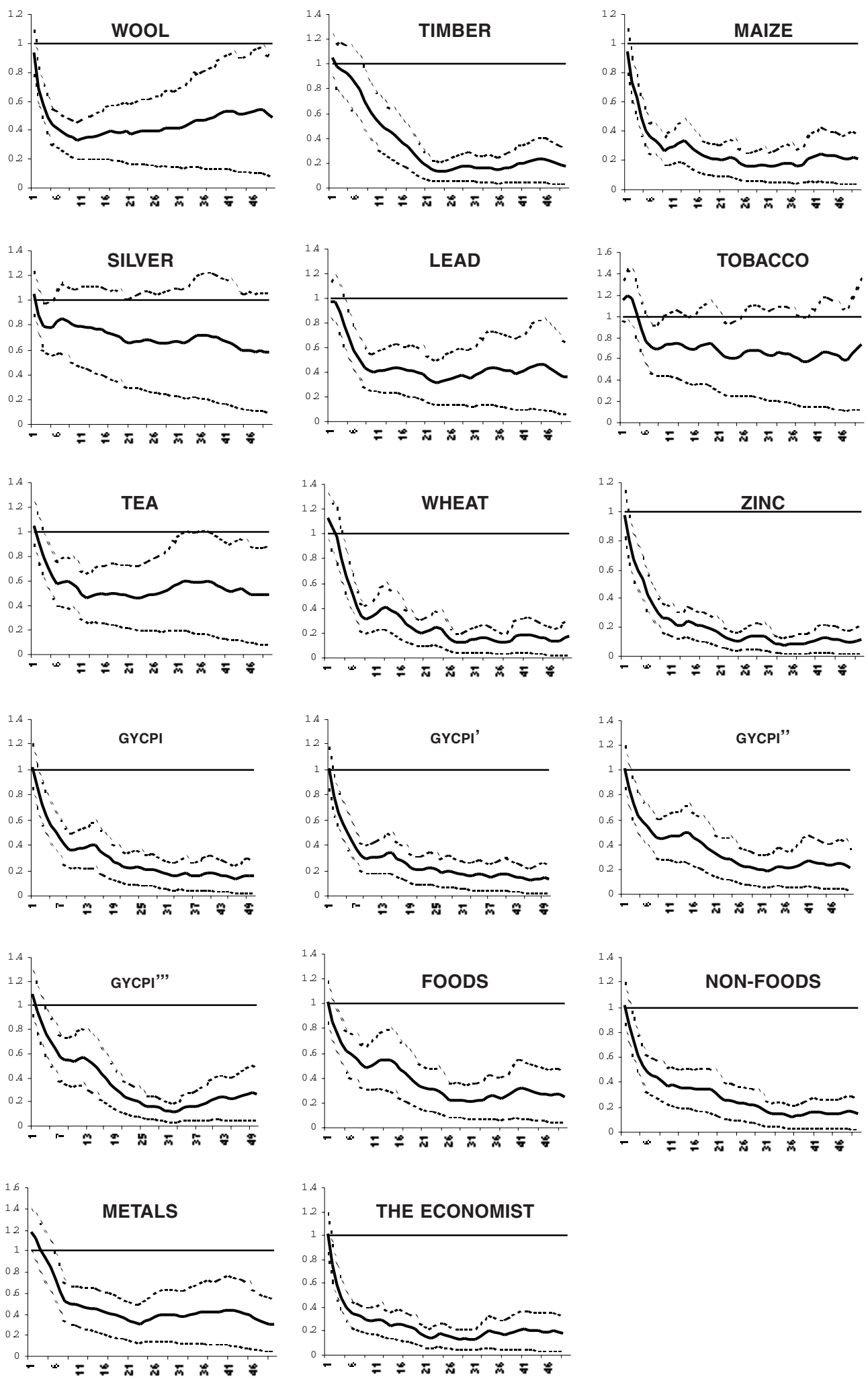

Source: Prepared by the authors. 
$\mathrm{V}$

\section{Structural breaks}

The first step in this direction is to analyse the possible presence of structural breaks in the series that probably follow the DT model. ${ }^{33}$ Following Cuddington, Ludema and Jayasuriya (2002), we first calculate the recursive residuals and the confidence bands for the hypothesis that the residuals come from the same distribution as that of the estimated model. We also show probabilities ( $p$-values) for an $N$-step forecast test for each possible sample. ${ }^{34}$ The results are given in appendix C. As can be seen there, for eight commodities (beef, hides, lamb, lead, palm oil, rubber, sugar and timber) these tests suggest the presence of a structural break around 1920. The same is true for all the overall indices and the food sub-index. In addition, five commodities and one index (coffee, jute, lead, palm oil and tin, and the GYCPI"') display a structural break around 1980. Lastly, rice, sugar, timber and the Economist index show a break around 1970.

To confirm the existence of these breaks, one of Perron's tests $(1997)^{35}$ is used to conduct an endogenous search for the point where a structural break occurs (box 3).

Cuddington, Ludema and Jayasuriya (2002) put forward four criticisms of this methodology and propose an alternative algorithm. The first criticism is that this is a test whose null hypothesis is the presence of a unit root, conditional on the presence of a structural break at an unknown date, and not a test for the presence of a structural break as such. The second is that it allows for only one structural break, whereas there is no reason in principle to believe that additional breaks may not be present. Thirdly, they identify as an implicit weakness the fact that the test allows for the structural break under the alternative hypothesis but not under the null hypothesis. Fourthly, the test assumes that the

\footnotetext{
${ }^{33}$ An interesting overview of the work done in this area can be found in Cuddington, Ludema and Jayasuriya (2002).

${ }^{34}$ The null hypothesis is that forecasting errors correspond to a model with no structural break. If the $p$-value is smaller than 0.01 , then the null hypothesis can be rejected with a $99 \%$ confidence level.

35 This procedure was written for the Regression Analysis of Time Series (RATS) software by G. Colletaz and F. Serranito of the Laboratoire d'économie d'Orléans, and is available at www.estima.com.
}

Box 3
PERRON's TEST
This test selects a break point that minimizes
the t-statistic for testing the null hypothesis of
a unit root. The test may be estimated according
to three possible models. The first allows only
for a one-time change in the intercept, which
occurs gradually. This is the innovational outlier
(IO1) model. The second model allows for a
change in both the intercept and the slope. This
is the innovational outlier with changing trend
(IO2) model. The third model allows for a
change in the slope, with no break in the trend
function. This is the additive outlier (AO)
model.

type of structural break is known in advance. Notwithstanding these criticisms, the test has been used in this paper in view of its simplicity and the availability of the relevant algorithm.

Since we do not have a structural form a priori for each of the variables and we wish to circumvent the last of the criticisms mentioned above, we estimated the three models and applied the test to all of them. The results for all the variables, which are given in appendix D, are consistent with the results of the $\mathrm{Vk}$ estimator for six of the eight commodities that are nonstationary according to the estimator (bananas, cocoa, cotton, silver, tea and tobacco), ${ }^{36}$ since it is not possible to reject the unit root hypothesis for these commodities at a $95 \%$ confidence level.

Eight commodities (beef, coffee, copper, jute, lamb, maize, timber and tin) and the GYCPI"” show no evidence of a structural break according to this test, but they also show no evidence of a unit root according to the Vk estimator. Nonetheless, it must be borne in mind that, for most of these commodities, ${ }^{37}$ this outcome is inconsistent with the results of the recursive residuals exercise (the case of these commodities will be re-examined in section VII).

\footnotetext{
${ }^{36}$ This is not the case with aluminium or wool.

${ }^{37}$ The exceptions are copper and maize.
} 
For eight commodities, lastly, the null hypothesis of a unit root can be rejected with a $95 \%$ confidence level with respect to the alternative hypothesis of a structural break. These commodities are hides, lead, palm oil, rice, rubber, sugar, wheat and zinc. The same is true of all the indices except the one that includes petroleum (GYCPI""). These results are consistent with the recursive residuals analysis, except in the cases of wheat, zinc and the GYCPI"'. It is clear, however, that the presence of a structural break does not preclude the possible presence of one or more additional breaks. This possibility is considered in section VII.

Table 2 gives the results for these eight commodities and for the seven indices that show a structural break according to the Perron test. These results may at first appear confusing and, in terms of pinpointing a specific year for the structural break, inconclusive. One third of the changes take place between 1910 and 1930 and more than a third between 1970 and 1990. While the selection of any time period is arbitrary, it is interesting to note that nine statistically significant changes can be detected in the period 1915-1925. Twelve more are found in 1973-1983 and eight more in 1941-1951. Thus, two thirds of the breaks detected took place in these three time periods. Considering this evidence and, particularly, the fact that these periods coincide with the three historical turning points in the world economy (the two world wars and the end of the "golden age" of growth in the industrialized economies), ${ }^{38}$ the DT and ST models will be estimated in the next section. The fact that breaks appear in more than one period will not be considered, however, until section VII. ${ }^{39}$

\footnotetext{
${ }^{38}$ See Maddison (1995) and ECLAC (2002).

${ }^{39}$ In particular, consideration will be given to those cases that show evidence of more than one structural break according to the recursive residuals test (lead, palm oil, sugar and the GYCPI").
}

Timing of structural breaks with null hypothesis of unit root ${ }^{a}$

\begin{tabular}{|c|c|c|c|c|c|c|}
\hline & $\begin{array}{l}\text { Innovational outlier } \\
\text { (intercept) }\end{array}$ & & $\begin{array}{l}\text { Innovational outlier } \\
\text { (intercept and }\end{array}$ & & $\begin{array}{l}\text { Additive outlier } \\
\text { (trend) }\end{array}$ & \\
\hline & IO1 & & $\mathrm{IO} 2$ & & $\mathrm{AO}$ & \\
\hline & $1900-2000$ & & $1900-2000$ & & $1900-2000$ & \\
\hline & UR & & UR & & UR & \\
\hline \multicolumn{7}{|l|}{ Commodity } \\
\hline Hides & 1950 & $* *$ & 1916 & $* *$ & 1905 & $* *$ \\
\hline Lead & 1978 & * & 1945 & $* *$ & 1973 & $* *$ \\
\hline Palm oil & 1917 & $* *$ & 1983 & $* * *$ & 1991 & $* *$ \\
\hline Rice & 1988 & & 1971 & $* *$ & 1975 & $* *$ \\
\hline Rubber & 1915 & $* *$ & 1934 & $* *$ & 1926 & * \\
\hline Sugar & 1979 & $* *$ & 1979 & & 1983 & \\
\hline Wheat & 1941 & $* * *$ & 1928 & $* *$ & 1910 & $* * *$ \\
\hline Zinc & 1920 & $* * *$ & 1920 & $*$ & 1928 & $* * *$ \\
\hline \multicolumn{7}{|l|}{ Index } \\
\hline GYCPI & 1944 & $* *$ & 1944 & $*$ & 1978 & * \\
\hline GYCPI' & 1948 & $* *$ & 1971 & $* *$ & 1929 & \\
\hline GYCPI" & 1983 & $* *$ & 1970 & & 1978 & $* *$ \\
\hline Metals & 1915 & $* *$ & 1951 & $*$ & 1940 & $* *$ \\
\hline Foods & 1983 & $* *$ & 1984 & & 1977 & * \\
\hline Non-foods & 1948 & $* *$ & 1938 & $* *$ & 1929 & * \\
\hline The Economist & 1915 & $* * *$ & 1915 & $* * *$ & 1920 & $* * *$ \\
\hline
\end{tabular}

Source: Authors' calculations.

a $*, * *$ and $* * *$ indicate statistical significance at $90 \%, 95 \%$ and $99 \%$ confidence, respectively. 


\section{VI}

\section{Estimating the dynamic of real commodity prices}

At this point, it would be useful to summarize the results obtained thus far:

- Trends in the prices of beef, coffee, copper, jute, lamb, maize, timber and tin and in the index that includes petroleum (GYCPI"') can be estimated according to a deterministic-trend (DT) model, using traditional econometric techniques. ${ }^{40}$

- Aluminium, banana, cocoa, cotton, silver, tea, tobacco and wool prices should be estimated according to a stochastic-trend (ST) model. ${ }^{41}$

- The presence of a structural break should be considered in relation to the remaining indices and to hides, lead, palm oil, rice, rubber, sugar, wheat and zinc.

This section presents estimates of these models to determine whether there is a statistically significant trend in those series that follow a deterministic trend or a drift in those that follow a stochastic trend, and to identify the effect of structural breaks on the remaining series. Section VII will cover, among other topics, the presence of more than one structural break and will accordingly re-estimate the models for all the variables that display at least one structural break in any of the tests.

Table 3 shows the results for the DT model estimated by the ordinary least squares (OLS) method, adding ARMA as required so that the residuals will be white noise. It is found that coffee, copper and tin do not show a statistically significant deterministic trend. Beef, lamb and timber, on the other hand, have shown a positive trend of over $1 \%$ a year. Lastly, jute, maize and the aggregate index that includes petroleum (GYCPI"') show a constant declining trend. Of course, a simple model like this one cannot completely capture the dynamic of the series.

\footnotetext{
40 The cases of beef, coffee, jute, lamb, timber and tin will be reexamined in section VII, as the two tests presented are not consistent and therefore do not preclude the possible presence of one or more structural breaks.

41 An interesting observation is that five of these commodities (aluminium, cocoa, cotton, tea and wool) are among those that display the steepest falls, as shown in table 1 . This will be taken into account in the subsequent analysis of the results of the ST model estimate.
}

Table 4 shows the results for the eight variables that manifest non-stationarity. In view of their wide variability, it is unsurprising that none of the drifts is statistically significant. ${ }^{42}$ The sign for all these commodities is negative, however, with the exception of tobacco. If these results are compared to those in table 1 , it becomes apparent that the five products that show a drift ${ }^{43}$ of close to $-1 \%$ declined by a cumulative total of nearly 60\% between 1900-1904 and 1996-2000. For these prices, then, negative shocks have clearly been more frequent than positive ones, and the conclusion is that they have deteriorated significantly.

Lastly, table 5 shows the results obtained by estimating the three models considered by Perron (see box 3). This table is organized on the basis that a structural break occurs at time $T b$. Accordingly, it shows the values of both the intercept and the trend, both before and after the structural break occurs. ${ }^{44}$

According to these results, the relative price trend for hides, lead, palm oil, rice, rubber, sugar ${ }^{45}$ and wheat has been systematically negative. ${ }^{46}$ The relative price trend for zinc has been systematically positive, but it exhibited a steep fall in 1920. If the value of $\beta$ is considered, it can be concluded that the trend has been constant and negative only in the case of sugar. In the other cases, $\beta$ obscures the fact that, for some commodities, the trend was not significant prior to the structural break (as in the cases of hides, lead, rice and wheat), whereas for others it lost statistical significance after the break, this being the case with palm oil and rubber (IO2).

Table 6 presents a similar analysis for the nonpetroleum aggregate price indices. Clearly, all of them show a systematic negative trend. However, for GYCPI, GYCPI" and the food sub-index, this trend was not

\footnotetext{
42 Cuddington, Ludema and Jayasuriya (2002) reach the same conclusion using the ST model for the GYCPI series.

${ }^{43}$ Not statistically significant.

44 The intercept for palm oil was 4.96 before 1917, for example, after which it was 5.09 . The trend, meanwhile, was $-0.72 \%$, taking this break into account. The trend changed again after 1991, from $-0.46 \%$ to $-3.4 \%$ per year, while the intercept remained at 4.90 .

45 This variable exhibited a sharp decline in 1979.

${ }^{46}$ Only the segments in which the trend is statistically significant have been considered.
} 
TABLE 3

Estimates of variables that follow a deterministic-trend (DT) process $^{\mathrm{a} / \mathrm{b}}$

(Real variables in logarithms)

\begin{tabular}{|c|c|c|c|c|c|c|c|c|c|c|c|c|c|}
\hline & $\mathrm{C}$ & & $\beta(\%)$ & & $\operatorname{AR}(1)$ & & $\mathrm{MA}(1)$ & & $\mathrm{MA}(2)$ & & $\mathrm{MA}(4)$ & & $\mathrm{R}^{2}$ \\
\hline Beef & 2.93 & $* * *$ & 1.46 & $* *$ & 0.86 & $* * *$ & & & & & & & 0.88 \\
\hline Coffee & 3.68 & $* * *$ & 0.21 & & 0.81 & $* * *$ & & & & & & & 0.67 \\
\hline Copper & 4.71 & $* * *$ & -0.25 & & 0.84 & $* * *$ & & & & & & & 0.72 \\
\hline Jute & 5.40 & $* * *$ & -1.07 & $* *$ & 0.91 & $* * *$ & & & -0.42 & $* * *$ & & & 0.72 \\
\hline Lamb & 2.86 & $* * *$ & 1.66 & $* * *$ & 0.81 & $* * *$ & & & & & 0.31 & $* * *$ & 0.89 \\
\hline Maize & 5.57 & $* * *$ & -1.29 & $* * *$ & 0.70 & $* * *$ & & & & & & & 0.79 \\
\hline Timber & 3.64 & $* * *$ & 1.02 & $* * *$ & 0.77 & $* * *$ & & & & & & & 0.87 \\
\hline Tin & 3.64 & $* * *$ & 0.32 & & 0.86 & $* * *$ & & & & & & & 0.76 \\
\hline GYCPI"", & 5.08 & $* * *$ & -0.72 & $* * *$ & 0.60 & $* * *$ & 0.44 & $* * *$ & & & & & 0.81 \\
\hline
\end{tabular}

Source: Authors' calculations.

${ }^{a} \mathrm{C}=$ constant $\beta=$ trend; $\mathrm{AR}(\mathrm{i})=$ autoregressive element of order $\mathrm{i} ; \mathrm{MA}(\mathrm{j})=$ moving average element of order $\mathrm{j} ; \mathrm{R}^{2}=$ coefficient of determination. $\mathrm{b} *, * *$ and $* * *$ indicate statistical significance at $90 \%, 95 \%$ and $99 \%$ confidence respectively.

TABLE 4

Stochastic-trend (ST) model estimates ${ }^{a / b}$

(Differences of real variables in logarithms)

\begin{tabular}{|c|c|c|c|c|c|c|c|c|c|c|c|c|}
\hline & $\mathrm{C}(\%)$ & $\operatorname{AR}(2)$ & & MA(1) & & MA(2) & & $\operatorname{MA}(3)$ & & MA(4) & & $\mathrm{R}^{2}$ \\
\hline Aluminium & -1.10 & & & 0.28 & $* * *$ & -0.20 & $* *$ & & & & & 0.13 \\
\hline Bananas & -0.01 & & & & & -0.21 & $* *$ & & & & & 0.03 \\
\hline Cocoa & -1.20 & -0.33 & $* * *$ & & & & & & & & & 0.11 \\
\hline Cotton & -1.13 & & & & & -0.28 & $* * *$ & -0.19 & $*$ & & & 0.14 \\
\hline Silver & -0.26 & & & & & -0.26 & $* *$ & & & & & 0.07 \\
\hline Tea & -0.82 & -0.24 & $* *$ & & & & & & & & & 0.06 \\
\hline Tobacco & 0.77 & & & & & & & & & -0.27 & $* * *$ & 0.08 \\
\hline Wool & -1.40 & & & & & -0.41 & $* * *$ & & & & & 0.13 \\
\hline
\end{tabular}

Source: Authors' calculations.

${ }^{\mathrm{a}} \mathrm{C}=$ constant $\beta=$ trend; $\mathrm{AR}(\mathrm{i})=$ autoregressive element of order $\mathrm{i} ; \mathrm{MA}(\mathrm{j})=$ moving average element of order $\mathrm{j} ; \mathrm{R}^{2}=$ coefficient of determination. $\mathrm{b} *, * *$ and $* * *$ indicate statistical significance at $90 \%, 95 \%$ and $99 \%$ confidence respectively.

significant prior to the structural break. Another noteworthy finding is the proportionate increase in the deterioration of GYCPI', the metals sub-index and the non-food sub-index after each structural break.

As little long-term information comparable to the price series analysed is available for productivity, transport costs and changes in product quality, it is difficult to include these variables in the statistical exercises. In any event, existing productivity series for the countries of the Organisation for Economic Cooperation and Development (OECD) show a break in the trend of relative labour productivity in agriculture and manufacturing in the 1950s: while manufacturing productivity had risen faster than agricultural productivity up to that time, the opposite was the case from then on (Bairoch, 1989; Maddison, 1991). This structural break is not, however, reflected in the statistical results analysed earlier. Furthermore, the long-term lead gained by agricultural productivity, as revealed by these data, would only suggest a relatively marginal decline in the agricultural terms of trade (about $0.2 \%$ a year). There are no comparable series for the developing world, and even if such series were available, they would be distorted by changes in the rural underemployment that characterized the developing countries throughout the twentieth century.

The series on productivity per hectare for seven agricultural products estimated by Scandizzo and Diakosawas (1987) and updated with information from the United Nations Food and Agriculture Organization

THE TERMS OF TRADE FOR COMMODITIES IN THE TWENTIETH CENTURY • JOSÉ ANTONIO OCAMPO AND MARÍA ÁNGELA PARRA 
TABLE 5

Commodity prices: Estimates of the deterministic-trend (DT) model, with structural breaks ${ }^{a / b}$

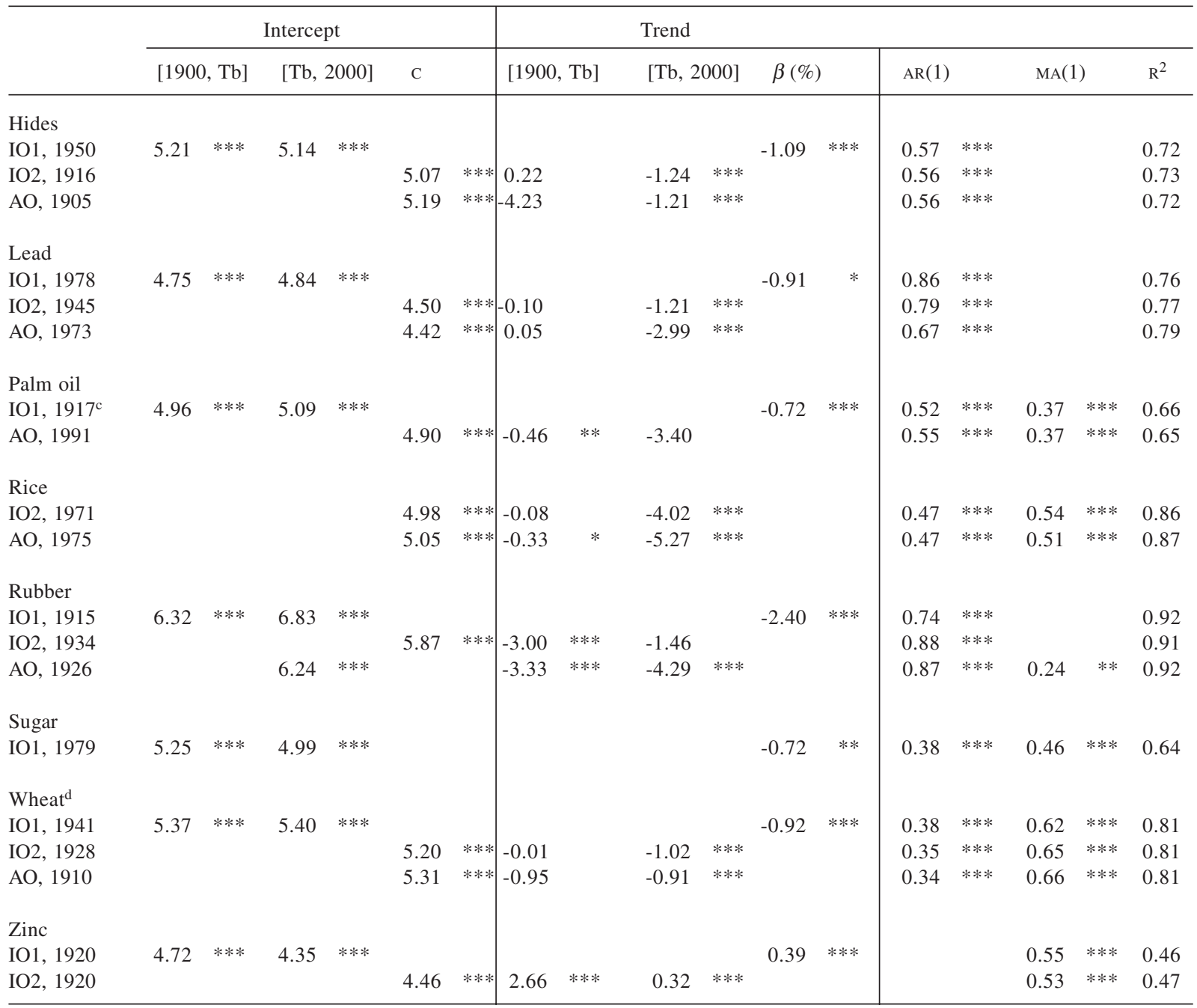

Source: Authors' calculations.

a $\mathrm{Tb}=$ date of structural break; $\mathrm{C}=$ constant; $\beta=$ trend; $\mathrm{AR}(\mathrm{i})=$ autoregressive element of order $\mathrm{i}$; $\mathrm{MA}(\mathrm{j})=$ moving average element of order $\mathrm{j} ; \mathrm{R}^{2}=$ coefficient of determination.

b $*, * *$ and $* * *$ indicate statistical significance at $90 \%, 95 \%$ and $99 \%$ confidence respectively.

c The definition of the IO1, IO2 and AO models is given in box 3 .

$\mathrm{d}$ The error structure of the equations reveals a misspecification, since ARMAs of an order higher than 2 are needed to correct the autocorrelation, and the AR(1) coefficient is greater than 1 .

(FAO) indicate annual productivity improvements of about $1 \%$ throughout the twentieth century, with the notable exception of coffee, for which productivity increased by just $0.2 \%$ a year between 1910-1914 and 1995-1999. The rate of productivity growth sped up between the 1960s and the 1980s in the case of three products that were affected by the "green revolution" (rice, maize and wheat). The inclusion of these productivity series in the statistical exercises does not, however, change the conclusions to be drawn concerning long-term real price trends; in fact, their impact on real prices seems to have been only partial and not always statistically significant. There are perhaps just two exceptions to this rule. First, the 
Price indices: Estimates of the DT model, with structural breaks ${ }^{a / b}$

\begin{tabular}{|c|c|c|c|c|c|c|c|c|c|c|c|c|c|c|c|c|c|}
\hline \multirow{3}{*}{ GYCPI } & \multicolumn{6}{|c|}{ Intercept } & \multicolumn{6}{|c|}{ Trend } & \multirow{2}{*}{\multicolumn{2}{|c|}{$\operatorname{AR}(1)$}} & \multirow{2}{*}{\multicolumn{2}{|c|}{$\mathrm{MA}(1)$}} & \multirow{3}{*}{$\mathrm{R}^{2}$} \\
\hline & \multicolumn{2}{|c|}{$[1900, \mathrm{~Tb}]$} & \multicolumn{2}{|c|}{$[\mathrm{Tb}, 2000]$} & \multicolumn{2}{|l|}{ C } & \multicolumn{2}{|c|}{$[1900, \mathrm{~Tb}]$} & \multicolumn{2}{|c|}{$[\mathrm{Tb}, 2000]$} & \multicolumn{2}{|l|}{$\beta(\%)$} & & & & & \\
\hline & & & & & & & & & & & \multirow{4}{*}{-0.81} & \multirow{4}{*}{$* * *$} & & & & & \\
\hline IO1, 1944 & 5.05 & $* * *$ & 5.11 & $* * *$ & & & & & & & & & 0.71 & $* * *$ & & & 0.83 \\
\hline IO2, 1944 & & & & & 4.85 & *** & -0.17 & & -1.02 & $* * *$ & & & 0.68 & $* * *$ & 0.25 & $*$ & 0.83 \\
\hline AO, 1978 & & & & & 4.81 & $* * *$ & -0.19 & & -2.94 & $* * *$ & & & 0.70 & $* * *$ & 0.22 & $*$ & 0.83 \\
\hline \multicolumn{18}{|l|}{ GYCPI' } \\
\hline IO1, 1948 & 5.17 & $* * *$ & 5.32 & $* * *$ & & & & & & & -1.01 & $* * *$ & 0.41 & $* * *$ & 0.41 & $* * *$ & 0.86 \\
\hline IO2, 1971 & & & & & 4.94 & $* * *$ & -0.34 & $* *$ & -2.54 & $* * *$ & & & 0.57 & $* * *$ & 0.34 & $* * *$ & 0.85 \\
\hline \multicolumn{18}{|l|}{ GYCPI" } \\
\hline IO1, 1983 & 5.16 & $* * *$ & 4.88 & $* * *$ & & & & & & & -0.72 & $* * *$ & 0.58 & $* * *$ & 0.30 & $* *$ & 0.89 \\
\hline AO, 1978 & & & & & 4.94 & $* * *$ & -0.20 & & -4.42 & $* * *$ & & & 0.67 & $* * *$ & 0.27 & $* *$ & 0.88 \\
\hline \multicolumn{18}{|l|}{ Metals } \\
\hline IO1, 1915 & 4.79 & $* * *$ & 5.14 & $* * *$ & & & & & & & -0.80 & $* *$ & 0.85 & $* * *$ & 0.30 & $* * *$ & 0.86 \\
\hline IO2, 1951 & & & & & 4.85 & $* * *$ & -0.39 & $*$ & -0.94 & $* *$ & & & 0.79 & $* * *$ & 0.36 & $* * *$ & 0.85 \\
\hline $\mathrm{AO}, 1940$ & & & & & 4.89 & $* * *$ & -0.56 & $*$ & -0.86 & $* *$ & & & 0.80 & $* * *$ & 0.42 & $* * *$ & 0.85 \\
\hline \multicolumn{18}{|l|}{ Foods } \\
\hline IO1, 1983 & 4.89 & $* * *$ & 4.54 & $* * *$ & & & & & & & -0.46 & $* *$ & 0.72 & $* * *$ & & & 0.83 \\
\hline AO, 1977 & & & & & 4.76 & $* * *$ & -0.14 & & -3.94 & $* * *$ & & & 0.51 & $* * *$ & 0.35 & $* *$ & 0.84 \\
\hline \multicolumn{18}{|l|}{ Non-foods } \\
\hline IO1, 1948 & 5.20 & $* * *$ & 5.32 & $* * *$ & & & & & & & -1.10 & $* * *$ & 0.52 & $* * *$ & 0.32 & $* *$ & 0.86 \\
\hline IO2, 1938 & & & & & 5.01 & $* * *$ & -0.60 & $* *$ & -1.30 & $* * *$ & & & 0.62 & $* * *$ & 0.35 & $* * *$ & 0.86 \\
\hline AO, 1929 & & & & & 4.94 & $* * *$ & 0.34 & & -0.95 & $* * *$ & & & 0.64 & $* * *$ & 0.31 & $* *$ & 0.86 \\
\hline \multicolumn{18}{|c|}{ The Economist } \\
\hline IO1, 1915 & 6.75 & $* * *$ & 7.04 & $* * *$ & & & & & & & -1.33 & $* * *$ & & & 0.67 & $* * *$ & 0.91 \\
\hline IO2, 1915 & & & & & 6.82 & $* * *$ & -1.58 & $* *$ & -1.26 & $* * *$ & & & & & 0.72 & $* * *$ & 0.90 \\
\hline $\mathrm{AO}, 1920$ & & & & & 6.75 & $* * *$ & -0.13 & & -1.27 & $* * *$ & & & 0.28 & $*$ & 0.53 & $* * *$ & 0.91 \\
\hline
\end{tabular}

Source: Authors' calculations.

a $\mathrm{Tb}=$ date of structural break; $\mathrm{C}=$ constant; $\beta=$ trend; AR(i) = autoregressive element of order $\mathrm{i}$; MA $(\mathrm{j})=$ moving average element of order $\mathrm{j} ; \mathrm{R}^{2}=$ coefficient of determination.

$\mathrm{b} *, * *$ and $* * *$ indicate statistical significance at $90 \%, 95 \%$ and $99 \%$ confidence respectively. The definition of the IO1, IO2 and AO models is given in box 3 .

absence of any long-term adverse trend in coffee prices may be related to slower productivity growth. Second, the structural break in real prices for rice in the early 1970 s may be associated with the green revolution (though maize and wheat did not show any such breaks).

In sum, coffee, copper and tin show no statistically significant deterministic trend. Likewise, aluminium, bananas, cocoa, cotton, silver, tea, tobacco and wool exhibit a drift that is not statistically significant. All of them, however, except silver and tobacco, have suffered a cumulative deterioration of nearly $60 \%$. On the other hand, beef, lamb and timber have shown a positive deterministic trend. Zinc has also followed a systematically positive trend. Lastly, jute, maize and the aggregate index GYCPI"' have followed a constant declining trend, while the relative price trend for hides, lead, palm oil, rice, rubber, sugar and wheat and all the other aggregate indices has been systematically negative. Therefore, 4 commodities show a positive trend; 11 show no statistically significant trend or drift, though 5 of them experienced a cumulative decline of nearly $60 \%$, indicating a strong predominance of negative shocks; and 9 show a stepwise or continuous negative trend. In the aggregate, commodities with 
negative trends or shocks prevail, and all indices thus show a systematic tendency to decline.

In general, given the scarcity of available information, no firm conclusions can be drawn about the impact of changes in relative agricultural productivity on the long-term trend or breaks in the trend of the terms of trade for these commodities over the twentieth century; even less can be inferred about the impact on their factorial terms of trade. As we pointed out in section III, the literature on the convergence or divergence of real wages and per capita income is more relevant for assessing the validity of what is referred to here as the second Prebisch-Singer hypothesis.

\section{VII}

\section{Multiple structural breaks}

The model estimation carried out in the preceding section on the basis of Perron's methodology (1997) reveals that, in the case of eight commodities and seven of the eight indices, there was at least one structural break in price trends in the course of the twentieth century. They also confirm that these breaks tended to worsen the terms of trade for commodities. This tends to substantiate our basic hypothesis that the deterioration of those prices took place in a stepwise fashion. Unfortunately, the methodology used so far allows for only a single structural break. ${ }^{47}$ This means that there is still room for another possible step to "hide" behind the statistical estimates. Indeed, this is suggested by the results of the recursive residuals analysis and the fact that the breaks are located around more than one period (see section V).

While it cannot be established with strict econometric rigour, the foregoing results and economic history itself imply that the biggest breaks were concentrated around 1920 and 1980. This suggests that they represent the delayed effects of the sharp slowdowns in the world economy after the First World War and after the first oil shock of the 1970s, which marked the end of the "golden age" of the industrialized economies (Maddison, 2001). More precisely, the following econometric analysis assumes that the breaks took place around 1921 and 1979, coinciding, respectively, with the severe international crisis that followed the First World War, whose effect on raw material prices is well known, and with the effects of

\footnotetext{
${ }^{47}$ Cuddington, Ludema and Jayasuriya (2002) present the results of a model that accommodates more than one structural break for the GYCPI series. However, that model could not be applied on a large scale to all the series included in this analysis owing to its econometric complexity.
}

the monetary policy adopted by the United States economic authorities to curb inflation. Statistical exercises were also performed to determine whether there was a structural break in the series at the end of the Second World War or shortly thereafter (around the time of the Korean War). Since the findings did not point to a significant statistical break at that time, they have not been reported in this paper.

Accordingly, the results and historical facts described warrant a final econometric exercise involving re-estimation of all the models ${ }^{48}$ except those that show a stochastic trend, assuming that structural breaks took place in 1921 and 1979. Table 7 contains the corresponding estimates, and figure 3 shows the results for the indices, excluding the ARMA dynamic of the residuals to illustrate more clearly the breaks and the deviations of prices from the estimated trends.

These exercises show that food prices rose considerably up until the First World War, whereas metals lost value. In terms of specific commodities, only a few (hides, palm oil, maize and timber, in particular) followed a rising trend, and only one (rubber) followed the opposite pattern.

In 1921, all the Grilli-Yang aggregate indices experienced a large, sudden decline (of between $44 \%$ and $52 \%$, depending on the aggregate index used), from which they failed to recover in subsequent decades. In terms of commodity groups, metals were the only

\footnotetext{
${ }^{48}$ Justifications for re-estimating all the stationary price series except copper and maize were presented in the preceding sections. These two commodities have been included to round out the analysis by covering all stationary series. Non-stationary variables cannot be estimated using traditional methods because, as shown earlier, these methods may generate spurious results.
} 
TABLE 7

Estimation of stationary series with structural breaks in 1921 and $1979^{a}$

\begin{tabular}{|c|c|c|c|c|c|c|c|c|c|c|c|c|c|c|c|c|c|}
\hline & $\mathrm{C}$ & $\mathrm{t} 021$ & & $\mathrm{c} 21$ & & $\mathrm{t} 2279$ & & c79 & & $\mathrm{t} 8000$ & & $\mathrm{AR}(1)$ & $\operatorname{AR}(2)$ & $\mathrm{AR}(4)$ & $\mathrm{MA}(1)$ & $\mathrm{MA}(2)$ & $\mathrm{MA}(4)$ \\
\hline \multicolumn{18}{|l|}{ Commodity } \\
\hline Beef & 3.03 & 0.72 & & -0.18 & & 2.49 & $* * *$ & 0.32 & & -4.28 & $* *$ & 0.80 & & & & & \\
\hline Coffee & 3.14 & 3.74 & & -0.41 & & 1.39 & $* *$ & -0.11 & & -4.11 & $* *$ & 0.73 & & & & & \\
\hline Copper & 5.03 & -1.38 & & -0.42 & $* * *$ & 0.85 & $* * *$ & -0.10 & & -2.22 & $* *$ & & & & 0.81 & 0.33 & \\
\hline Hides $^{b}$ & 4.82 & 3.29 & $* * *$ & -0.63 & $* * *$ & -1.10 & $* * *$ & 0.37 & $* *$ & -3.58 & $* * *$ & & & & 0.52 & & \\
\hline Jute & 4.57 & 2.66 & $*$ & -0.28 & & 0.19 & & -0.32 & $*$ & -2.90 & $* *$ & 0.31 & & & 0.51 & & \\
\hline Lamb & 2.66 & 3.23 & & -0.16 & & 1.84 & $* *$ & 0.34 & & -1.46 & & 0.79 & & & & & 0.36 \\
\hline Lead & 4.35 & 1.11 & & -0.28 & $*$ & 0.22 & & 0.14 & & -5.60 & $* * *$ & 0.76 & & & & & \\
\hline Maize & 4.90 & 3.30 & $* * *$ & -0.44 & $* * *$ & -0.54 & $* * *$ & -0.20 & & -3.73 & & & & & 0.55 & & \\
\hline Palm oil & 4.67 & 3.20 & $* *$ & -0.53 & $* * *$ & -0.41 & & -0.27 & $*$ & 1.12 & & & & & 0.82 & 0.27 & \\
\hline Rice & 5.28 & -1.86 & & 0.12 & & -0.42 & $*$ & -0.31 & $* *$ & -3.13 & $* * *$ & & & & 0.91 & 0.26 & \\
\hline Rubber & 7.38 & -6.62 & $* * *$ & -0.67 & $* *$ & -1.06 & $* * *$ & -0.33 & $*$ & -2.00 & & 1.62 & -0.74 & & -1.00 & & \\
\hline Sugar & 5.20 & 2.58 & & -1.04 & $* * *$ & 0.34 & & -0.33 & & -2.01 & & -0.48 & & & 1.39 & 0.63 & \\
\hline Timber & 3.16 & 5.22 & $* * *$ & -0.41 & $* * *$ & 1.08 & $* * *$ & -0.00 & & 0.76 & & 0.70 & & & & & \\
\hline Tin & 3.50 & 1.17 & & -0.36 & $*$ & 1.64 & $* * *$ & 0.09 & & -5.01 & $* * *$ & 0.67 & & & & & \\
\hline Wheat & 5.08 & 1.72 & $*$ & -0.31 & $* *$ & -0.66 & $* * *$ & -0.03 & & -1.78 & $* *$ & 0.35 & & -0.26 & 0.52 & & \\
\hline Zinc & 4.65 & 0.81 & $* *$ & -0.42 & $* * *$ & 0.59 & $* *$ & -0.03 & & -0.32 & & & & & 0.69 & 0.21 & \\
\hline \multicolumn{18}{|l|}{ Indices } \\
\hline GYCPI & 4.91 & 1.24 & $* *$ & -0.49 & $* * *$ & -0.08 & & -0.06 & & -1.94 & $* * *$ & & & & 0.82 & 0.29 & \\
\hline GYCPI' & 5.06 & 0.67 & & -0.44 & $* * *$ & -0.18 & & -0.02 & & -2.15 & $* * *$ & & & & 0.80 & 0.25 & \\
\hline GYCPI" & 4.95 & 1.84 & $* *$ & -0.48 & $* * *$ & -0.29 & $*$ & -0.06 & & -3.35 & $* * *$ & & & & 0.85 & 0.29 & \\
\hline GYCPI", & 4.86 & 2.10 & $* *$ & -0.52 & $* * *$ & -0.30 & & 0.17 & & -3.09 & $* * *$ & & & & 0.98 & 0.38 & \\
\hline Metals & 5.46 & -2.82 & $* *$ & -0.19 & & -0.21 & & 0.12 & & -1.66 & $*$ & 0.59 & & & 0.41 & & \\
\hline Foods & 4.57 & 3.05 & $* * *$ & -0.60 & $* * *$ & 0.09 & & -0.11 & & -3.61 & $* * *$ & 0.37 & & & 0.51 & & \\
\hline Non-foods & 5.11 & 0.45 & & -0.44 & $* * *$ & -0.33 & $*$ & -0.01 & & -2.19 & $* * *$ & & & & 0.82 & 0.30 & \\
\hline The Economist & 6.47 & 2.12 & $* * *$ & -0.20 & $* *$ & -1.17 & $* * *$ & -0.02 & & -2.06 & $* * *$ & & & & 0.67 & & \\
\hline
\end{tabular}

Source: Authors' calculations.

${ }^{a} \mathrm{C}=$ constant; $\beta=$ trend; $\operatorname{AR}(\mathrm{i})=$ autoregressive element of order $\mathrm{i} ; \mathrm{MA}(\mathrm{j})=$ moving average element of order $\mathrm{j}$; $\mathrm{R}^{2}=\mathrm{coefficient}$ of determination.

b Does not converge.

exception to this rule. The decline is statistically significant, although of varying magnitudes, for 11 out of 16 commodities. Interestingly, this drop was followed by a long period (1922-1979) in which aggregate price indices followed no statistically significant trend. This occurred because the different prices moved in opposite directions.

Lastly, in contrast to what had happened in 1921, in 1979 there was no sudden drop in prices, but rather a break in the price trend, which became strongly negative from then on (with declines of $2 \%$ to $3 \%$ a year for the various sub-indices). This trend was very pronounced for food and less so for metals; moreover, it was negative for 14 of the 16 commodities included in table 7, although it was statistically significant for only 9. A closer analysis might indicate that the decline was concentrated in the $1980 \mathrm{~s},{ }^{49}$ in which case this phenomenon would be more similar to what took place in 1921, albeit more gradual over time.

Lastly, it should be pointed out that the Economist series also displays a stepwise dynamic, although this differs from that of the Grilli-Yang indices. In particular, the 1921 adjustment is smaller (20\%) in the Economist series, but it shows a strong, statistically significant negative trend in the period 1922-1979 (1.2\% a year), picking up speed after 1979. Thus, as figure 3 illustrates, this series follows a much more secular trend towards deterioration from the 1920s onward.

${ }^{49}$ See Maizels (1999) for an analysis of changes in raw materials prices in that decade. 
FIGURE 3

Estimation of aggregate price indices incorporating multiple structural breaks
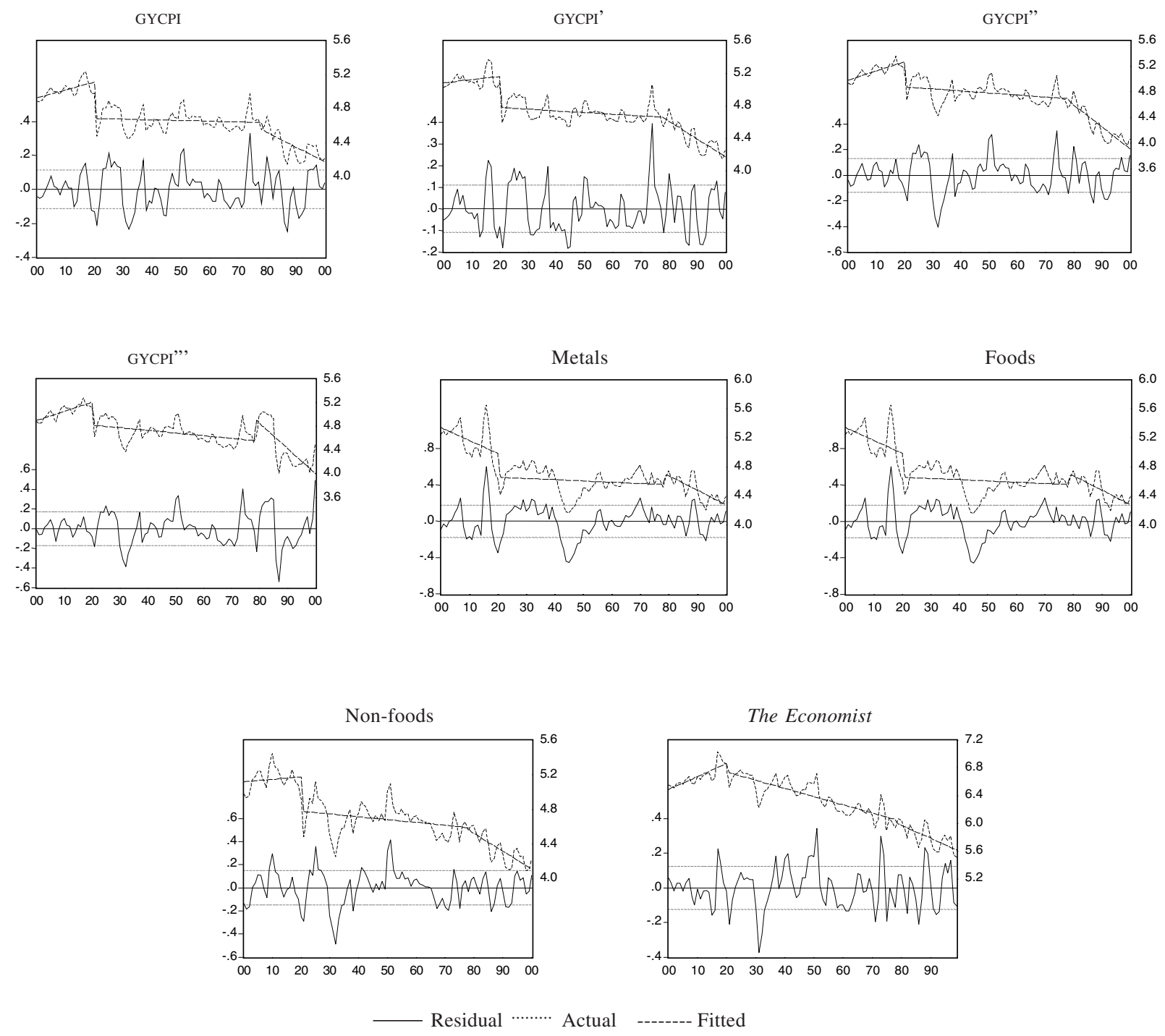

Source: Prepared by the authors.

The statistical exercises therefore seem to indicate that the reduction in real commodity prices throughout the twentieth century resulted from two major structural breaks that took place around 1921 and 1979. The first of these breaks took the form of a sudden, one-time drop in prices, and the second took the form of a shift in the price trend.
To complete this overview, the following section briefly analyses the speed with which the series reverted to the mean in response to short-term shocks. If this took place slowly, it would imply that shortterm shocks had a long-lasting effect on economic performance. 


\section{VIII}

\section{Short- and medium-term shocks and variability}

The Vk estimator, which was used in section IV to determine the long-term persistence of innovations, is also useful for analysing the series' reaction to shortand medium-term shocks without resorting to methodologies based on parameterizations that give too much weight to dynamic characteristics of a short-term nature. The speed with which the estimator tends to zero shows how a shock is dissipated. Following the methodology of León and Soto (1995b), table 8 illustrates the behaviour of this estimator for variables that do not present non-stationarity characteristics.

The table shows that nine commodities display a significant mean reversion process in the first five years after a shock. In six cases (hides, jute, maize, sugar, wool and zinc), the shock has dissipated by $40 \%$ within the first four years. In three cases (coffee, palm oil and rice) the reduction is $25 \%$. When the same parameters are applied to the indices, all of them except the index that includes petroleum and the metals price index show a high speed of mean reversion. After this initial reversion, the process continues at a slower pace, so that after more than 25 years only nine commodities have returned to long-term equilibrium ( $\mathrm{Vk}<0.26)$.

Viewed from a macroeconomic standpoint, these results show that, while reversion to the mean is relatively rapid, the effects of a shock last for more than a year, and therefore have an impact in both the short and medium terms. This indicates that stabilization funds are a viable option, but the reference prices used by such funds must change to take account of market prices if their use is not to lead to large-scale fiscal losses.

TABLE 8

Estimation of the mean reversion process

(Value of the Vk statistic)

\begin{tabular}{|c|c|c|c|c|c|c|c|c|}
\hline Year & 1 & 2 & 3 & 4 & 5 & 10 & 15 & 28 \\
\hline \multicolumn{9}{|l|}{ Commodity } \\
\hline Beef & 1.04 & 0.97 & 0.97 & 0.99 & 0.96 & 0.79 & 0.70 & 0.47 \\
\hline Coffee & 0.98 & 0.82 & 0.77 & 0.75 & 0.71 & 0.61 & 0.46 & 0.23 \\
\hline Copper & 1.04 & 0.97 & 0.89 & 0.78 & 0.67 & 0.45 & 0.49 & 0.54 \\
\hline Hides & 0.86 & 0.66 & 0.58 & 0.49 & 0.40 & 0.24 & 0.24 & 0.10 \\
\hline Jute & 0.97 & 0.74 & 0.69 & 0.60 & 0.50 & 0.30 & 0.37 & 0.33 \\
\hline Lamb & 1.01 & 0.89 & 0.82 & 0.92 & 0.94 & 0.90 & 0.70 & 0.41 \\
\hline Lead & 0.98 & 0.98 & 0.89 & 0.77 & 0.67 & 0.40 & 0.44 & 0.37 \\
\hline Maize & 0.94 & 0.74 & 0.64 & 0.50 & 0.40 & 0.28 & 0.27 & 0.16 \\
\hline Palm oil & 1.05 & 0.90 & 0.77 & 0.71 & 0.61 & 0.39 & 0.29 & 0.16 \\
\hline Rice & 1.15 & 1.02 & 0.88 & 0.74 & 0.66 & 0.48 & 0.33 & 0.25 \\
\hline Rubber & 1.07 & 1.03 & 0.95 & 0.87 & 0.80 & 0.43 & 0.40 & 0.35 \\
\hline Sugar & 0.98 & 0.75 & 0.65 & 0.55 & 0.45 & 0.36 & 0.27 & 0.13 \\
\hline Timber & 1.06 & 0.97 & 0.96 & 0.93 & 0.89 & 0.56 & 0.40 & 0.17 \\
\hline Tin & 1.00 & 1.01 & 0.93 & 0.88 & 0.80 & 0.63 & 0.58 & 0.34 \\
\hline Wheat & 1.13 & 1.05 & 0.98 & 0.81 & 0.65 & 0.33 & 0.35 & 0.12 \\
\hline Wool & 0.93 & 0.69 & 0.58 & 0.49 & 0.43 & 0.33 & 0.37 & 0.41 \\
\hline Zinc & 0.98 & 0.80 & 0.67 & 0.60 & 0.53 & 0.26 & 0.23 & 0.14 \\
\hline \multicolumn{9}{|l|}{ Index } \\
\hline GYCPI & 1.02 & 0.87 & 0.74 & 0.63 & 0.57 & 0.36 & 0.40 & 0.21 \\
\hline GYCPI' & 1.01 & 0.79 & 0.66 & 0.58 & 0.50 & 0.30 & 0.34 & 0.20 \\
\hline GYCPI" & 1.02 & 0.85 & 0.73 & 0.64 & 0.58 & 0.46 & 0.49 & 0.22 \\
\hline GYCPI", & 1.10 & 0.95 & 0.86 & 0.76 & 0.70 & 0.54 & 0.49 & 0.16 \\
\hline Metals & 1.18 & 1.11 & 1.02 & 0.94 & 0.84 & 0.49 & 0.44 & 0.39 \\
\hline Foods & 1.01 & 0.85 & 0.77 & 0.68 & 0.62 & 0.50 & 0.52 & 0.23 \\
\hline Non-foods & 1.03 & 0.86 & 0.74 & 0.61 & 0.52 & 0.37 & 0.36 & 0.22 \\
\hline The Economist & 1.01 & 0.76 & 0.59 & 0.48 & 0.40 & 0.29 & 0.25 & 0.13 \\
\hline
\end{tabular}

Source: Authors' calculations. 


\section{IX}

\section{Conclusions}

The econometric findings presented in this paper do not provide evidence of a secular or continuous trend towards the erosion of the terms of trade. It is nevertheless a fact that relative raw materials prices deteriorated markedly in the course of the twentieth century. Various tests confirm that there has been a decline, whether stepwise or continuous, in the prices of nine commodities and in all the indices. Meanwhile, eight commodities present a unit root and high volatility; it is therefore not surprising that their drift, although negative in all cases but one, is not statistically significant. At the same time, however, five of them present a cumulative decline of nearly $60 \%$, indicating that negative shocks far outweighed positive ones. Lastly, four products have followed a rising trend, while three others show no significant deterministic trend.
Since all the non-petroleum indices show evidence of structural breaks, it is affirmed here, in the light of both the information generated from the tests and the historical evidence, that the first downward step seems to have taken place around 1920 and was related to the major changes produced in the global economy by the First World War. The second structural break seems to have occurred around 1980, in the wake of the world economic slowdown that began in 1973. Econometric analysis confirms the presence of these steps in different ways. Whereas the first case involved a substantial onetime adjustment in commodity prices, the second case involved an adverse break in the price trend. Prices followed a more positive trend before the First World War, and there is no clear evidence of a significant trend between the 1920s and the 1970s.

APPENDIX A

\section{Methodology used to update price indices}

John Cuddington generously provided data on the prices of the 24 individual commodities used by Grilli and Yang (1988). This information was then updated from 1987 by ECLAC on the basis of statistics provided by the United Nations Conference on Trade and Development (UNCTAD), the International Monetary Fund (IMF), the World Bank and the Organization of Petroleum Exporting Countries (OPEC). These series were then used to update the price indices (four aggregate indices and three sub-indices) presented by Grilli and Yang (1988).

The first of the aggregate indices (GYCPI) is a price index that weights commodities by their share of world exports in 1977-1979. These weightings, which were published by Cuddington and Wei (1998), were used to update the index to 2000. The second index (GYCPI') was weighted by the developing countries' share of commodity exports in 19771979. The original weightings are unavailable, so weightings were developed for 1981 on the basis of COMTRADE ${ }^{50}$ data and the index was then recalculated for the entire century.
Figure A.1 shows both the original series and the new one, in real terms. The differences between the two are concentrated in the years prior to 1950 . Nonetheless, the trends are similar except during the years of the First World War, when the new weightings amplify the upswing in the price index.

Grilli and Yang's other two aggregate indices (GYCPI" and GYCPI" ) have variable weightings based on the share of world exports represented by commodities in different years. The difference between the two is that the second of these indices includes petroleum. Variable weightings for the current year were calculated by ECLAC on the basis of COMTRADE data and were then used to update these indices. The resultant series are shown in table A.1.

${ }^{50}$ Foreign trade statistics database operated by the Statistics Division of the United Nations Department of Economic and Social Affairs. 
FIGURE A.1

\section{Real price index, weighted by developing countries' share} of commodity exports

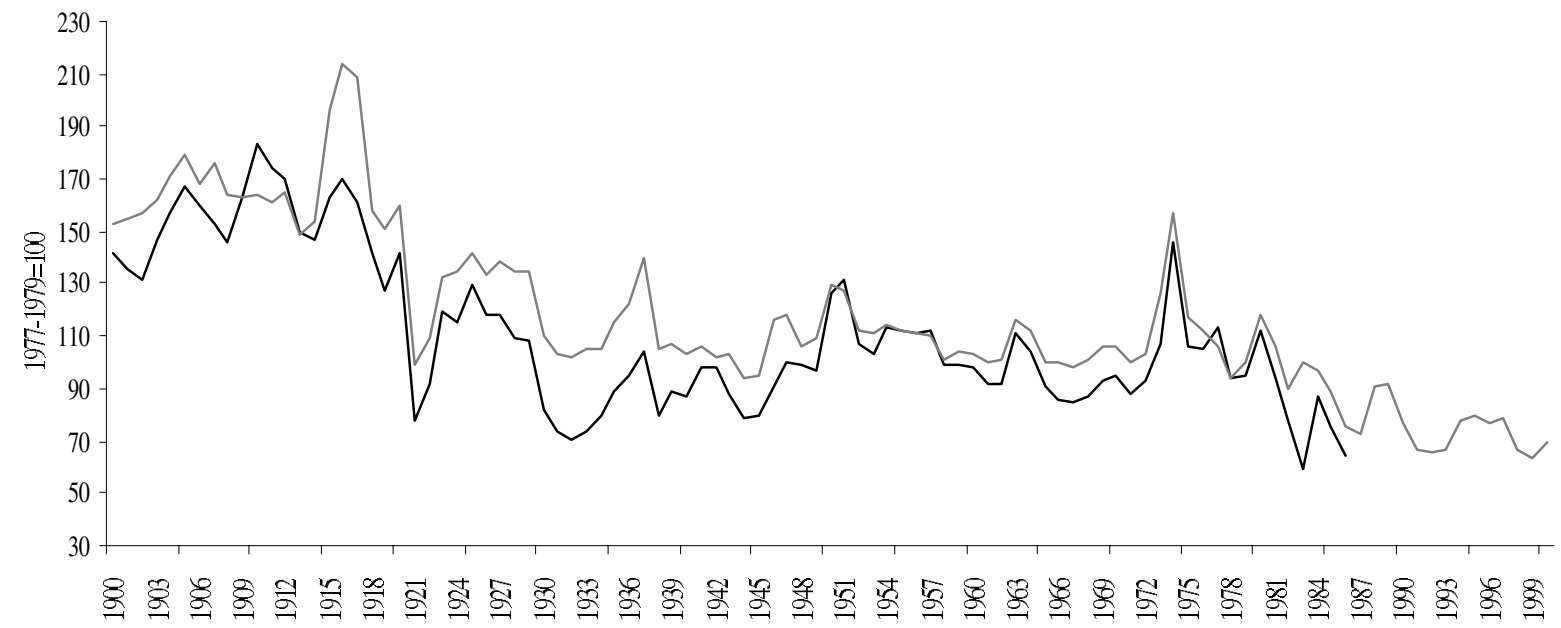

Share in 1977-1979 _— Share in 1981

Source: Grilli and Yang (1988) and ECLAC calculations based on United Nations data.

TABLE A.1

Updating of Grilli and Yang's price indices (1988)

$(1977-1979=100)$

\begin{tabular}{rrrrrrrr}
\hline & & & & & \multicolumn{3}{c}{ GYCPI sub-indices } \\
\cline { 6 - 9 } & GYCPI & GYCPI' & GYCPI" & GYCPI" & Foods & Non-foods & Metals \\
\hline 1986 & 88.36 & 98.42 & 90.79 & 93.76 & 75.78 & 102.58 & 134.42 \\
1987 & 93.61 & 107.56 & 92.56 & 81.28 & 90.54 & 124.55 & 180.99 \\
1988 & 118.92 & 142.86 & 117.15 & 114.38 & 91.50 & 128.97 & 178.08 \\
1989 & 123.29 & 143.19 & 116.13 & 120.54 & 86.67 & 125.89 & 157.21 \\
1990 & 120.81 & 131.66 & 108.60 & 132.39 & 83.97 & 106.87 & 128.75 \\
1991 & 109.78 & 115.15 & 96.77 & 118.55 & 84.44 & 107.25 & 129.28 \\
1992 & 113.93 & 115.63 & 95.79 & 110.09 & 82.80 & 102.75 & 111.69 \\
1993 & 109.25 & 111.43 & 91.96 & 102.60 & 102.04 & 131.04 & 133.96 \\
1994 & 138.01 & 133.97 & 108.45 & 109.15 & 105.53 & 146.73 & 157.42 \\
1995 & 149.71 & 149.57 & 117.79 & 118.84 & 108.12 & 128.56 & 141.00 \\
1996 & 141.99 & 140.56 & 108.81 & 121.87 & 107.14 & 119.68 & 141.69 \\
1997 & 133.75 & 133.36 & 107.57 & 118.27 & 93.35 & 98.84 & 120.37 \\
1998 & 112.35 & 109.70 & 90.82 & 92.25 & 81.77 & 98.06 & 118.00 \\
1999 & 107.01 & 102.46 & 85.61 & 101.53 & 75.03 & 105.75 & 126.19 \\
2000 & 105.57 & 109.50 & 90.87 & 138.72 & 73.10 & 103.67 & 120.80 \\
\hline
\end{tabular}

Source: Grilli and Yang (1988) and ECLAC calculations based on United Nations data.

a GYCPI: Dollar-denominated price index for 24 internationally traded non-petroleum commodities, weighted by each commodity's share of total exports in 1977-1979.

GYCPI': Dollar-denominated price index for 24 internationally traded non-petroleum commodities, weighted by the developing countries' share of commodity exports in 1981.

GYCPI": Dollar-denominated price index for 24 internationally traded non-petroleum commodities, weighted by the share of world exports represented by commodities during the current year.

GYCPI"": The same as GYCPI" except that it includes the petroleum price.

THE TERMS OF TRADE FOR COMMODITIES IN THE TWENTIETH CENTURY • JOSÉ ANTONIO OCAMPO AND MARÍA ÁNGELA PARRA 
APPENDIX B

Unit root tests for the logarithm of the series in real terms

\begin{tabular}{|c|c|c|c|c|}
\hline & $\begin{array}{c}\text { Augmented } \\
\text { Dickey-Fuller statistic }\end{array}$ & Significance ${ }^{b}$ & $\begin{array}{l}\text { Phillips-Perron } \\
\text { statistic }\end{array}$ & Significance $\mathrm{e}^{\mathrm{b}}$ \\
\hline Aluminium $^{c}$ & -2.21 & & -2.40 & \\
\hline Bananas ${ }^{c}$ & -2.04 & & -2.59 & \\
\hline Beef $^{c}$ & -2.84 & & -2.78 & \\
\hline $\mathrm{Cocoa}^{\mathrm{c}}$ & -2.21 & & -2.46 & \\
\hline Coffee $^{c}$ & -2.55 & & -3.05 & \\
\hline Copper ${ }^{\mathrm{c}}$ & -2.23 & & -2.98 & \\
\hline Cotton $^{\mathrm{c}}$ & -1.72 & & -2.38 & \\
\hline Hides & -3.71 & $* *$ & -5.10 & $* * *$ \\
\hline Jute & -2.31 & & -3.24 & * \\
\hline Lamb & -3.50 & $* *$ & -3.06 & \\
\hline Lead $^{\mathrm{c}}$ & -1.94 & & -2.72 & \\
\hline Maize & -2.49 & & -4.21 & $* * *$ \\
\hline Palm oil & -3.99 & $* *$ & -4.22 & $* * *$ \\
\hline Rice & -2.41 & & -3.16 & $*$ \\
\hline Rubber & -3.03 & & -3.34 & $*$ \\
\hline Silver ${ }^{\mathrm{c}}$ & -1.98 & & -2.31 & \\
\hline Sugar & -3.09 & & -4.49 & $* * *$ \\
\hline $\mathrm{Tea}^{\mathrm{c}}$ & -1.80 & & -2.39 & \\
\hline Timber & -3.98 & $* *$ & -3.80 & $* *$ \\
\hline $\operatorname{Tin}^{\mathrm{c}}$ & -2.33 & & -2.70 & \\
\hline Tobacco $^{c}$ & -1.05 & & -1.90 & \\
\hline Wheat & -3.90 & & -4.37 & $* * *$ \\
\hline Wool $^{\mathrm{c}}$ & -2.04 & $* *$ & -2.80 & \\
\hline Zinc & -4.09 & $* * *$ & -4.84 & $* * *$ \\
\hline GYCPI & -2.82 & & -3.86 & $* *$ \\
\hline GYCPI’ & -2.83 & & -4.09 & $* * *$ \\
\hline GYCPI" & -2.25 & & -3.29 & $*$ \\
\hline GYCPI", & -3.06 & & -3.67 & $* *$ \\
\hline Foods & -2.12 & & -2.97 & \\
\hline Non-foods & -2.67 & & -3.91 & $* *$ \\
\hline Metals & -2.94 & & -3.13 & \\
\hline The Economist & -3.64 & $* *$ & -3.89 & $* *$ \\
\hline
\end{tabular}

Source: Authors' calculations.

${ }^{\text {a }}$ Four lags are used.

b Significance in the event that the null hypothesis is rejected.

$*, * *$ and $* * *$ indicate statistical significance at $99 \%, 95 \%$ and $90 \%$ confidence, respectively.

c Series for which the null hypothesis could not be rejected on the basis of either of the two tests. 
APPENDIX C

\section{Recursive residuals test for the existence of structural breaks}
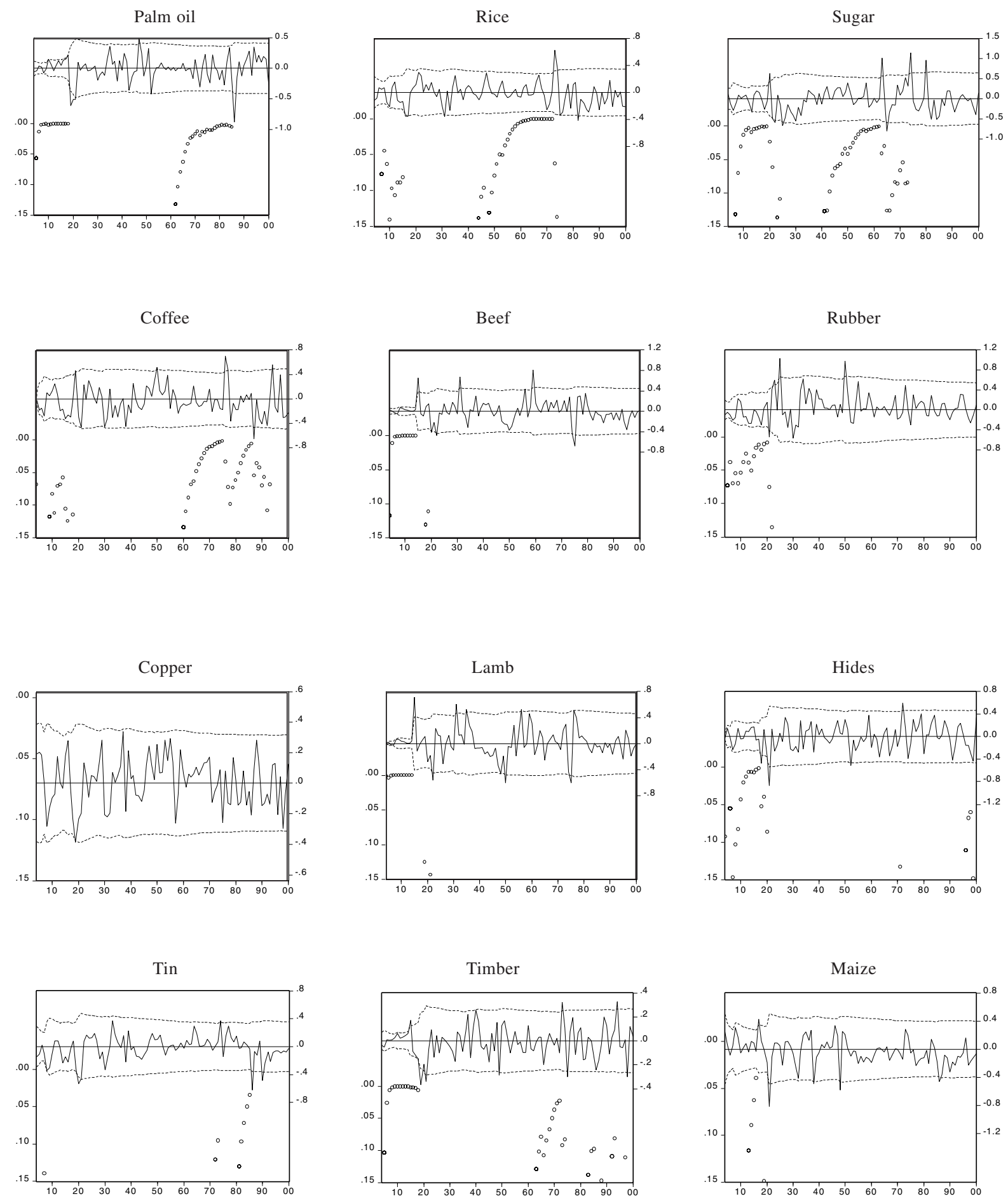

(continued on following page) 
Appendix C (continued)

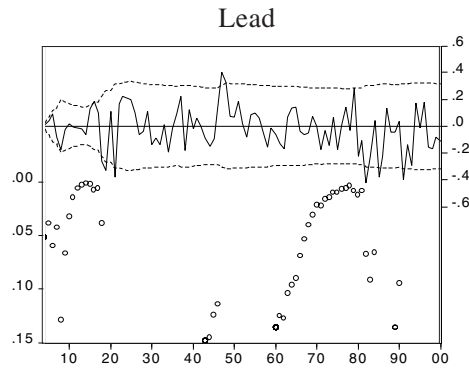

Zinc

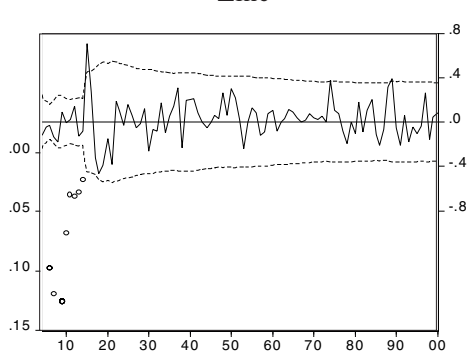

GYCPI"

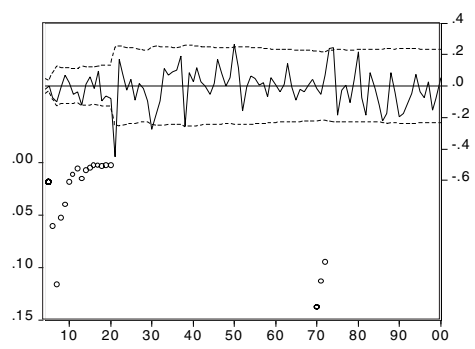

Non-foods



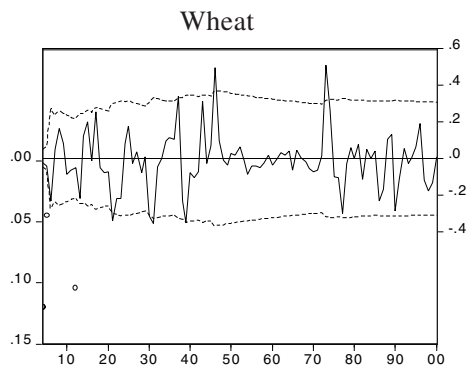

GYCPI

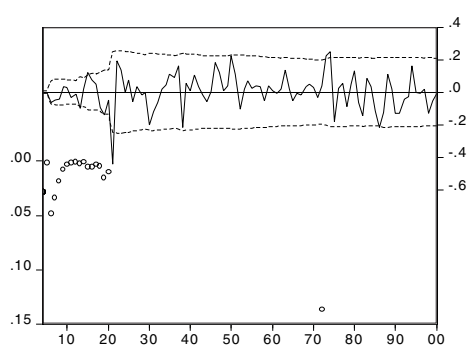

GYCPI",

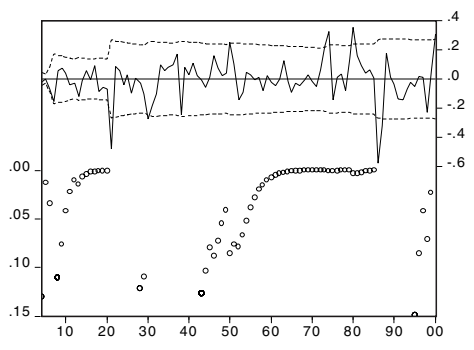

Metals

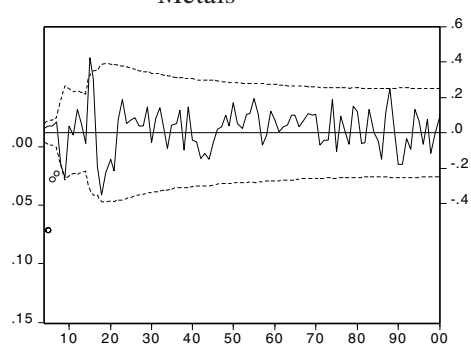

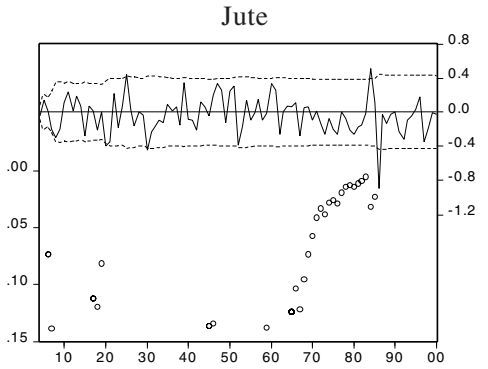

GYCPI'

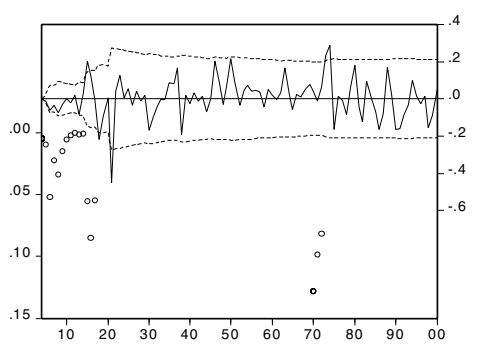

Foods

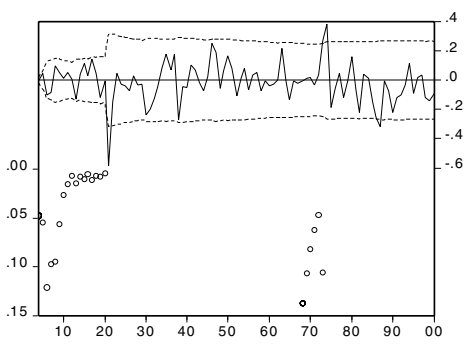

The Economist

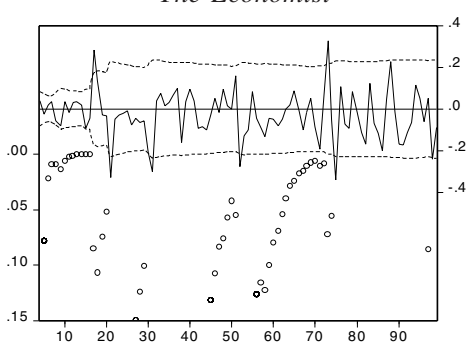

Source: Prepared by the authors. 
APPENDIX D

Perron test for endogenous determination of the date of a structural break

\begin{tabular}{|c|c|c|c|c|c|c|}
\hline & & nnova & outlier & & Additi & \\
\hline & Intercept & & Intercept and tre & & & \\
\hline & IO1 & & $\mathrm{IO} 2$ & & $\mathrm{AO}$ & \\
\hline & $1900-2000$ & & $1900-2000$ & & $1900-2000$ & \\
\hline & Unit root & & Unit root & & Unit root & \\
\hline Aluminium & 1938 & & 1940 & & 1948 & $* *$ \\
\hline Bananas & 1923 & & 1943 & & 1941 & $*$ \\
\hline Beef & 1957 & & 1957 & & 1982 & \\
\hline Cocoa & 1945 & & 1965 & & 1998 & $*$ \\
\hline Coffee & 1985 & & 1947 & & 1974 & \\
\hline Copper & 1951 & * & 1951 & & 1925 & \\
\hline Cotton & 1983 & & 1944 & & 1965 & \\
\hline Hides & 1950 & $* *$ & 1916 & $* *$ & 1905 & $* *$ \\
\hline Jute & 1944 & & 1958 & & 1971 & \\
\hline Lamb & 1945 & & 1945 & & 1926 & \\
\hline Lead & 1978 & * & 1945 & $* *$ & 1973 & $* *$ \\
\hline Maize & 1984 & & 1971 & & 1963 & \\
\hline Palm oil & 1917 & $* *$ & 1983 & $* * *$ & 1991 & $* *$ \\
\hline Rice & 1988 & & 1971 & $* *$ & 1975 & ** \\
\hline Rubber & 1915 & $* *$ & 1934 & $* *$ & 1926 & $*$ \\
\hline Silver & 1960 & & 1971 & & 1933 & \\
\hline Sugar & 1979 & $* *$ & 1979 & & 1983 & \\
\hline Tea & 1983 & & 1951 & & 1962 & \\
\hline Timber & 1912 & & 1920 & & 1913 & \\
\hline Tin & 1984 & & 1972 & & 1985 & \\
\hline Tobacco & 1915 & & 1946 & & 1964 & \\
\hline Wheat & 1941 & $* * *$ & 1928 & $* *$ & 1910 & $* * *$ \\
\hline Wool & 1972 & & 1946 & $* * *$ & 1953 & $* * *$ \\
\hline Zinc & 1920 & $* * *$ & 1920 & $*$ & 1928 & $* * *$ \\
\hline GYCPI & 1944 & $* *$ & 1944 & * & 1978 & $*$ \\
\hline GYCPI’ & 1948 & $* *$ & 1971 & $* *$ & 1929 & \\
\hline GYCPI" & 1983 & $* *$ & 1970 & & 1978 & $* *$ \\
\hline GYCPI"” & 1928 & & 1977 & & 1994 & \\
\hline Metals & 1915 & $* *$ & 1951 & $*$ & 1940 & $* *$ \\
\hline Foods & 1983 & $* *$ & 1984 & & 1977 & $*$ \\
\hline Non-foods & 1948 & $* *$ & 1938 & $* *$ & 1929 & $*$ \\
\hline The Economist & 1915 & $* * *$ & 1915 & $* *$ & 1920 & $* * *$ \\
\hline
\end{tabular}

Source: Authors' calculations.

a $*, * *$ and $* * *$ indicate statistical significance at $90 \%, 95 \%$ and $99 \%$ confidence, respectively. 


\section{Bibliography}

Ardeni, P.G. and B. Wright (1992): The Prebisch-Singer hypothesis: A reappraisal independent of stationarity hypothesis, The Economic Journal, vol. 102, No. 413, Oxford, Blackwell Publishers.

Bairoch, P. (1989): Les trois révolutions agricoles du monde développé: rendements et productivité de 1800 à 1985, Annales: économies, sociétés, civilisations, vol. 44, No. 2, Paris, March-April.

Beveridge, S. and C.R. Nelson (1981): A new approach to decomposition of economic time series into permanent and transitory components with particular attention to measurement of the 'business cycle', Journal of Monetary Economics, vol. 7, No. 2, Amsterdam, Elsevier Science Publisher, March.

Bleaney, M. and D. Greenaway (1993): Long-run trends in the relative price of primary commodities and in the terms of trade of developing countries, Oxford Economic Papers, vol. 45, No. 3, Oxford, Oxford University Press.

Campbell, J.Y. and G.N. Mankiw (1987): Are output fluctuations transitory?, The Quarterly Journal of Economics, vol. 102, No. 4, Massachusetts, The MIT Press.

Cashin, P. and C.J. McDermott (2002): The long-run behaviour of commodity prices: Small trends and big variability, IMF Staff Papers, vol. 49, No. 2, Washington, D.C., International Monetary Fund (IMF).

Cochrane, J.H. (1988): How big is the random walk in GNP?, Journal of Political Economy, vol. 96, No. 5, Chicago, University of Chicago Press.

(1991): A critique of the application of unit root tests, Journal of Economic Dynamics and Control, vol. 15, Amsterdam, Elsevier Science Publisher.

Cuddington, J.T. (1992): Long-run trends in 26 primary commodity prices: a disaggregated look at the Prebisch-Singer hypothesis, Journal of Development Economics, vol. 39, No. 2, Amsterdam, Elsevier Science Publisher.

Cuddington, J.T. and C.M. Urzúa (1989): Trends and cycles in the net barter terms of trade: a new approach, The Economic Journal, vol. 99, No. 396, Oxford, Blackwell Publishers.

Cuddington, J.T. and S.-J. Wei (1998): An empirical analysis of real commodity price trends: Aggregation, model selection and implications, in H.W. Singer, N. Hatti and R. Tandon (comps.), Export led versus balanced growth in the 1990's, New World Order Series, vol. 13, New Delhi, BR Publishing Corporation.

Cuddington, J.T., R. Ludema and S.A. Jayasuriya (2002): PrebischSinger redux, Working document, No. 140, Santiago, Chile, Central Bank.

ECLAC (Economic Commission for Latin America and the Caribbean) (2002): Globalization and Development, LC/G.2157(SES.29/3), Santiago, Chile, April.

Findlay, R. (1980): The terms of trade and equilibrium growth in the world economy, American Economic Review, vol. 70, No. 3, Nashville, Tennessee, American Economic Association. (1981): The fundamental determinants of the terms of trade, in S. Grassman and E. Lündberg (comps.), The world economic order: Past and prospects, London, Macmillan Press.

Grilli, E.R. and M.C. Yang (1988): Primary commodity prices, manufactured goods prices, and the terms of trade of developing countries: What the long run shows, The World Bank Economic Review, vol. 2, No. 1, Washington, D.C., World Bank.

Hadass, Y.S. and J.G. Williamson (2001): Terms of trade shocks and economic performance 1870-1940: Prebisch and Singer revisited, National Bureau of Economic Research Working Paper, No. 8188, Cambridge, Massachusetts, National Bureau of Economic Research (NBER).

Johnson, H.G. (1954): Increasing productivity, income-price trends and the trade balance, reprinted in International Trade and Economic Growth, Cambridge, Massachusetts, Harvard University Press, 1967.

León, J. and R. Soto (1995a): Términos de intercambio en la América Latina: una cuantificación de la hipótesis de Raúl Prebisch y Singer, El Trimestre Económico, vol. 62(2), No. 246, Mexico City, Fondo de Cultura Económica, April-June.

(1995b): Structural breaks and long run trends in commodity prices, Policy Research Working Paper, No. 1406, Washington, D.C., Policy Research Department, World Bank.

Lo, A. and C. McKinley (1989): The size and power of the variance ratio test in finite samples: a Montecarlo investigation, Journal of Econometrics, vol. 40, Amsterdam, Elsevier Science Publisher.

Maddison, A. (1991): Dynamic forces in capitalist development: A long-run comparative view, New York, Oxford University Press.

(1995): Monitoring the world economy 1820-1992, Paris, OECD Development Centre.

(2001): The world economy, a millennial perspective, Development Centre Studies, Paris, Organisation for Economic Co-operation and Development (OECD).

Maizels, A. (1999): The commodity price collapse of the 1980's, in D. Greenaway and C.W. Morgan (comps.), The economics of commodity markets, Cheltenham, Edward Elgar.

Ocampo, J.A. (1986): New developments in trade theory and LDCs, Journal of Development Economics, vol. 22, No. 1, Amsterdam, Elsevier Science Publisher, June.

(1993): Terms of trade and center-periphery relations, in Osvaldo Sunkel (comp.), Development from within: Toward a neostructuralist approach for Latin America, Boulder and London, Lynne Rienner Publishers.

Perron, P. (1989): The great crash, the oil price shock, and the unit root hypothesis, Econometrica, vol. 57, No. 6, Evanston, Illinois, The Econometric Society.

(1997): Further evidence on breaking trend functions in macroeconomic variables, Journal of Econometrics, vol. 80, No. 2, Amsterdam, Elsevier Science Publisher, October.

Powell, A. (1991): Commodity and developing countries terms of trade: what does the long-run show?, The Economic Journal, vol. 101, Oxford, Blackwell Publishers.

Prebisch, R. (1950): Growth, disequilibrium and disparities: interpretation of the process of economic development, Economic Survey of Latin America, 1949, E/CN.12/164/Rev. 1, New York, United Nations. Later published as Interpretación del proceso de desarrollo latinoamericano en 1949, Serie Conmemorativa del 25 aniversario de la CEPAL, Santiago, Chile, 1973.

(1962): The economic development of Latin America and its principal problems, Economic Bulletin for Latin America, 
vol. 7, No. 1, United Nations. Reprinting of the article published in English and Spanish in 1950.

Scandizzo, P.L. and D. Diakosawas (1987): Instability in the terms of trade of primary commodities, 1900-1982, FAO Economic and Social Development Paper, No. 64, Rome, Food and Agriculture Organization of the United Nations (FAO).
Singer, H.W. (1950): U.S. foreign investment in underdeveloped areas, the distribution of gains between investing and borrowing countries, American Economic Review, Papers and Proceedings, No. 40, Nashville, Tennessee, American Economic Association.

Taylor, L. (1983): Structuralist macroeconomics: Applicable models for the third world, New York, Basic Books. 